\title{
WAGE, INELATION AND EMPLOYMENT 2009 DYNAMICS WITH LABOUR MARKET MATCHING
}

Kai chistoffer, James costain.

Gregon de N Walque, Keith Kuester, Tobias sinzen, Stephen Anillard and onivier Pierrard

Documentos de Trabajo N.0918

\section{BANCODEESPANA}

\author{
Eurosistema
}


WAGE, INFLATION AND EMPLOYMENT DYNAMICS WITH LABOUR

MARKET MATCHING ${ }^{(*)}$

\author{
Kai Christoffel \\ EUROPEAN CENTRAL BANK \\ James Costain \\ BANCO DE ESPAÑA \\ Gregory de Walque \\ BANQUE NATIONALE DE BELGIQUE \\ Keith Kuester \\ FEDERAL RESERVE BANK OF PHILADELPHIA \\ Tobias Linzert \\ EUROPEAN CENTRAL BANK \\ Stephen Millard \\ BANK OF ENGLAND \\ Olivier Pierrard \\ BANQUE CENTRALE DU LUXEMBOURG
}

(*) Corresponding author: Kuester, keith.kuester@phil.frb.org, Christoffel: kai.christoffel@ecb.int, Costain: james.costain@bde.es, de Walque: gregory.dewalque@nbb.be, Linzert: tobias.linzert@ecb.int, Millard: stephen.millard@bankofengland.co.uk, Pierrard: Olivier.Pierrard@bcl.lu. We would like to thank Raf Wouters and seminar participants of the Eurosystem Wage Dynamics Network, the ESSIM 2008, the North American Summer Meeting of the Econometric Society 2009, and at Norges Bank for helpful comments. The views expressed in this paper are those of the authors and do not necessarily reflect the views held by the European Central Bank, any other central bank in the Eurosystem, the Bank of England, the Federal Reserve Bank of Philadelphia or the Federal Reserve System. 
The Working Paper Series seeks to disseminate original research in economics and finance. All papers have been anonymously refereed. By publishing these papers, the Banco de España aims to contribute to economic analysis and, in particular, to knowledge of the Spanish economy and its international environment.

The opinions and analyses in the Working Paper Series are the responsibility of the authors and, therefore, do not necessarily coincide with those of the Banco de España or the Eurosystem.

The Banco de España disseminates its main reports and most of its publications via the INTERNET at the following website: http://www.bde.es.

Reproduction for educational and non-commercial purposes is permitted provided that the source is acknowledged.

(C) BANCO DE ESPAÑA, Madrid, 2009

ISSN: 0213-2710 (print)

ISSN: 1579-8666 (on line)

Depósito legal: M. 36446-2009

Unidad de Publicaciones, Banco de España 


\section{Abstract}

In a search and matching environment, this paper assesses a range of modeling setups against macro evidence for the monetary transmission mechanism in the euro area. In particular, we assess right-to-manage vs. efficient bargaining, flexible vs. sticky wages, interactions at the firm level between price and wage-setting, alternative forms of hiring frictions, search on-the-job and endogenous job separation. Models with wage stickiness and right-to-manage bargaining or with firm-specific labour imply a sufficient degree of real rigidity, and so can reproduce inflation dynamics well. However, they imply too small a response on the employment margin. The other model variants fit employment dynamics better, but then imply too little real rigidity and, so, too volatile inflation, owing to strong responses of marginal wages and hours per employee. Further sources of real rigidities - possibly from outside of the labour market - seem to be needed to simultaneously explain the responses of wages, inflation and employment.

JEL Classification: E31,E32,E24,J64.

Keywords: Inflation Dynamics, Labour Market, Business Cycle, Real Rigidities. 


\section{Introduction and motivation}

A long tradition in monetary economics has assigned employment and wage-setting frictions a central role in economic dynamics, and inflation dynamics in particular. Yet alternative recent approaches to modeling the labour market imply very different employment and wage dynamics. Once implanted into an environment that gives a role for monetary policy, these differences translate into different effects of monetary policy on these series, and stark differences in the predictions for price setting and inflation. For example, some authors, e.g., Trigari (2009) and Walsh (2005), argue that accounting for equilibrium unemployment increases the resilience of inflation to shocks. Others, e.g., Krause and Lubik (2007), find that it removes traditional channels, say from sticky wages to inflation. Yet other variants have been assessed against the real-side responses alone. ${ }^{1}$

This paper contributes to the literature by assessing, in a New Keynesian business cycle model, the empirical performance in terms of employment, inflation and wage dynamics of a large number of previously proposed labor market variants, all built around the Mortensen and Pissarides (1994) model of search and matching frictions. In order to put the model variants on the same footing for the horse race, we use a calibration for the euro area that is harmonised across these variants. We assess the models against stylised facts of the monetary transmission process, asking whether any of the proposed variants provides a reasonable fit to the macro data in all three dimensions: wage, inflation, and employment responses to monetary shocks. Since the previous literature has emphasised that some of the variants can be sensitive to the details of the calibration, e.g., Hagedorn and Manovskii (2008), we carry out a sensitivity analysis. Besides the horse race, a contribution of this paper is that we theoretically compare this variety of variants with regard to the mechanisms that drive inflation, wage and employment dynamics in each.

We choose the efficient bargaining version of Trigari (2006) as our point of departure:

\footnotetext{
${ }^{1}$ Another strand of literature has been concerned with normative implications, such as the design of optimal monetary policy; see, e.g., Blanchard and Gali (2006).
} 
that is, a simple New Keynesian model with search and matching frictions and a distinction between heads and hours, with the timing simplified so that matches may be realised immediately instead of requiring a one-period lag. Building on this, we replace certain assumptions about the labour market structure by others, one at a time. We consider the following variants: right-to-manage (RTM) bargaining (Trigari (2006)), stickiness of wages in these setups (Gertler and Trigari (2006), Hall (2005) and Christoffel and Linzert (2005)) differentiating between stickiness in new matches and existing matches (Bodart et al. (2005) and (2006)), interactions at the firm-level between price and wage-setting (Kuester (2007), Sveen and Weinke (2007) and Thomas (2008)), alternative forms of vacancy posting costs (Yashiv (2006)), search on-the-job (Krause and Lubik (2006) and van Zandweghe (2009)) and endogenous separation (den Haan et al. (2000) and Trigari (2009)).

Our findings are as follows. In the baseline calibration many of the models imply a response of inflation that is much too large relative to the data. This is due to the strong role of marginal wages in explaining inflation dynamics, and their strong response to monetary policy, in these models. This response, in turn, rests on an unreasonably strong reaction of hours per worker; this is the case for the efficient bargaining versions with and without sticky wages, search on-the-job, the variants with variations in hiring costs, and endogenous separation. The other variants do better for inflation dynamics, indeed implying a little bit too much (as opposed to too little) real rigidity; this is the case for the RTM model with sticky wages and the model with firm-specific labour. On the downside, the latter model variants imply that much of the adjustment of employment is achieved through hours per worker rather than the number of heads, which is at odds with the data.

Changing the calibration towards a lower curvature of the disutility of hours worked per worker, or a higher outside option brings the inflation responses in the first block of models closer to the data. Yet the additional real rigidity now requires too much of a response of unemployment. We conclude that none of these, admittedly simple, variants fully matches the evidence on the monetary transmission mechanism in the 
euro area. These results would suggest either that the labour market is not a sufficiently strong source of real rigidities, and that other sources of real rigidity should be modeled, or that the specific way of modeling the labour market does not capture the way the labour market affects inflation dynamics in practice.

The rest of the paper is structured as follows. In section 2, we lay out the baseline model. Section 3, calibrates the model to euro-area data and establishes some stylised facts for the monetary transmission mechanism. When comparing the responses to a monetary easing in the baseline model to the stylised facts, we find that the inflation response is too strong: the model lacks real rigidities. Also, the unemployment response is too weak. Section 4 therefore presents the alternative modeling variants that we assess, and benchmarks these against the evidence. Section 5 summarizes the results and presents a sensitivity analysis. A final section concludes.

\section{The baseline model}

In this section we lay out our baseline model, a simplified version of Trigari's (2006) efficient bargaining model.

\subsection{Households, consumption and saving}

We assume that there is a continuum of workers indexed by $j$ on the unit interval who supply a homogeneous type of labour. Only a proportion $n_{t}$ of them are employed. We adopt a representative - or large - household interpretation. Household members (workers) share their labour income, i.e., wage and unemployment benefits, before choosing per capita consumption and bond holdings. Labour income is made of the sum of hourly wages, $w_{t}$, weighted by total hours worked, $n_{t} h_{t}$, and unemployment benefits, $b$, weighted by the number of unemployed, $1-n_{t}$. As shareholders, households also receive the profits $\Psi_{t}$ generated by the monopolistically-competitive retail firms and the intermediate producers of labour services.

If we momentarily leave aside the labour supply decision, which is taken by the house- 
hold as a whole, worker $j$ 's maximisation program is

$$
\max _{c_{j t}, B_{j t+1}} E_{t}\left\{\sum_{i=0}^{\infty} \beta^{i}\left[\frac{c_{j, t+i}^{1-\sigma_{c}}}{1-\sigma_{c}}-\chi \frac{h_{j, t+i}^{1+\phi}}{1+\phi}\right]\right\}
$$

subject to

$$
\frac{B_{j t}}{R_{t} P_{t}}+c_{j t}+t_{t}=\frac{B_{j t-1}}{P_{t}}+n_{t} w_{t} h_{t}+\left(1-n_{t}\right) b+\Psi_{t}
$$

where $\sigma_{c} \geq 1, \chi>0, \phi>0 .{ }^{2}$ Workers hold their financial wealth in the form of one-period bonds, $B_{j t}$, with price $1 / R_{t}$ (where $R_{t}$ is the nominal interest rate), $c_{j t}$ represents consumption, $h_{j t}$ hours worked, $t_{t}$ are lump-sum taxes payable and $P_{t}$ is the consumer price index. Due to additive separability of consumption and leisure and income pooling, individual consumption $c_{j t}$ coincides with aggregate consumption, $c_{t}$. The corresponding consumption Euler equation is

$$
\frac{\lambda_{t}}{P_{t}}=\beta R_{t} \mathrm{E}_{t}\left\{\frac{\lambda_{t+1}}{P_{t+1}}\right\},
$$

where $\lambda_{t}=c_{t}^{-\sigma_{c}}$.

\section{$2.2 \quad$ Firms}

The economy consists of three sectors: a perfectly-competitive final good sector, a monopolistically-competitive retail sector and a perfectly-competitive intermediate good sector.

\subsubsection{Final goods sector}

There is a continuum of differentiated goods indexed by $i$ on the unit interval. Final good firms aggregate the differentiated goods $y_{t}(i)$ produced by the retailers into a

\footnotetext{
${ }^{2}$ Some of the previous literature, e.g., Krause and Lubik (2007), abstract from allowing for an intensive margin of employment adjustment, alluding to the fact that employment fluctuates by more than hours per worker in the data. As a result, marginal costs depend directly on the shadow value of an additional job. Instead, we allow for labor adjustment on the intensive margin, which renders the cost of adjusting hours the marginal cost for the firm, viewing the relative use of the two margins as an equilibrium outcome. The shadow value of the job still matters implicitly as it is a determinant of the hourly wage.
} 
homogeneous consumption good using a Dixit-Stiglitz technology

$$
y_{t}=\left[\int_{0}^{1}\left[y_{t}(i)\right]^{\mu_{p}} d i\right]^{1 / \mu_{p}} \text { with } \mu_{p} \in(0,1),
$$

where $1 / \mu_{p}$ represents the retailers' gross price mark-up while $1 /\left(1-\mu_{p}\right)$ is the elasticity of substitution between intermediate differentiated goods. Each final good firm maximises profit, leading to the following demand for intermediate good $i$

$$
y_{t}(i)=\left(\frac{P_{t}(i)}{P_{t}}\right)^{\frac{1}{\mu_{p}-1}} y_{t}
$$

where $p_{t}$ is the final good price, obtained by aggregation of the retailers' prices

$$
P_{t}=\left[\int_{0}^{1}\left[P_{t}(i)\right]^{\frac{\mu_{p}}{\mu_{p}-1}} d i\right]^{\frac{\mu_{p}-1}{\mu_{p}}}
$$

The modeling of the final good sector remains unchanged throughout the paper.

\subsubsection{Monopolistic retailers and price setting}

Given the demand $y_{t}(i)$ that retail firm $i$ faces for its product, it buys a homogeneous intermediate labour good at nominal price $P_{t} x_{t}$ per unit and transforms it one for one into a differentiated product. In each period, a fraction $1-\xi_{p}$ of retail firms sets a new price $P_{t}^{*}$. This price prevails $j$ periods later with probability $\xi_{p}^{j}$. Profit maximisation results in the following first-order condition

$$
\mathrm{E}_{t} \sum_{j=0}^{\infty} \beta_{t, t+j}\left(\xi_{p}\right)^{j} \frac{y_{t+j}(i)}{P_{t+j}}\left(P_{t}^{*}-\frac{1}{\mu_{p}} P_{t+j} x_{t+j}\right)=0
$$

where $\beta_{t, t+j}=\beta^{j} \frac{\lambda_{t+j}}{\lambda_{t}}$ denotes the stochastic discount factor and $P_{t}^{*}$ denotes the optimal price. Log-linearising around the steady state gives the New Keynesian Phillips curve

$$
\hat{\pi}_{t}=\beta \mathrm{E}_{t} \hat{\pi}_{t+1}+\frac{\left(1-\xi_{p}\right)\left(1-\beta \xi_{p}\right)}{\xi_{p}} \hat{x}_{t}
$$


where $\pi_{t}=P_{t} / P_{t-1}$ is the inflation rate while 'hats' denote percentage deviations from steady state. The response of inflation depends on how real marginal cost, $\hat{x}_{t}$, responds to that shock. The labour market is the key to this response.

\subsubsection{Intermediate labor goods sector}

In the baseline model, there are a continuum of intermediate labour good producers who sell their output in a competitive market. Their only factor of production is labour. Following Mortensen and Pissarides (1999), we assume that intermediate producers can hire at most one worker so that their production is either zero or

$$
y_{t}^{l}(o)=\left[h_{t}(o)\right]^{\alpha} \text { with } \alpha<1
$$

where $o$ indicates firm-worker match $o$.

\subsection{Labour market}

The labour market links the intermediate good firms and the workers.

\subsubsection{Labour market flows}

Let $m_{t}$ denote the number of new firm-worker matches. These follow a linear homogeneous matching function:

$$
m_{t}=\sigma_{m}\left(u_{t}^{s}\right)^{\vartheta} v_{t}^{1-\vartheta}
$$

where $v_{t}$ is the number of job vacancies and $u_{t}^{s}$ the number of effective job seekers, with $\sigma_{m}>0$ and $\vartheta \in(0,1)$. In the baseline, the probability that an unemployed worker finds a job is given by

$$
s_{t}=\frac{m_{t}}{u_{t}^{s}}
$$

while the probability that a firm fills a vacancy is given by

$$
q_{t}=\frac{m_{t}}{v_{t}}
$$


An exogenous proportion $\rho$ of firm-worker relationships ends each period. This implies the following employment dynamics:

$$
n_{t}=(1-\rho) n_{t-1}+m_{t}
$$

Note that our timing assumption allows some workers and vacancies to find matches immediately, that is without spending a full period unemployed, as in Blanchard and Galí (2009). This timing appears appropriate for empirical work given that our simulations will be performed at a quarterly frequency. Most importantly, it allows shocks to be absorbed by unemployment rather than hours per worker which helps several of the model variants better replicate the data. ${ }^{3}$ Finally, unemployment will be given by $u_{t}=1-n_{t}$ and the number of searching workers by $u_{t}^{s}=u_{t-1}+\rho n_{t-1}$.

\subsubsection{Value of a job and a vacancy for the firms}

Firms and workers bargain over wages and hours worked. We denote by $\mathcal{J}_{t}$ and $\mathcal{V}_{t}$, respectively, the asset value of a job and of a vacancy at period $t$, dropping the match index for convenience:

$$
\begin{aligned}
& \mathcal{J}_{t}=y_{t}^{l} x_{t}-h_{t} w_{t}+\mathrm{E}_{t}\left\{\beta_{t, t+1}(1-\rho) \mathcal{J}_{t+1}\right\} \\
& \mathcal{V}_{t}=-\kappa+q_{t} \mathcal{J}_{t}+\mathrm{E}_{t}\left\{\beta_{t, t+1}\left(1-q_{t}\right) \mathcal{V}_{t+1}\right\}
\end{aligned}
$$

where $\kappa$ represents the real per-period search cost for firms.

\subsubsection{Value of a job and value of unemployment for a household}

To a worker's family, which bargains on her behalf, the value of a job is given by

$$
\mathcal{W}_{t}=h_{t} w_{t}-\frac{\chi}{\lambda_{t}} \frac{h_{t}^{1+\phi}}{1+\phi}+\mathrm{E}_{t}\left\{\beta_{t, t+1}\left[\left(1-\rho+\rho s_{t+1}\right) \mathcal{W}_{t+1}+\rho\left(1-s_{t+1}\right) \mathcal{U}_{t+1}\right]\right\}
$$

\footnotetext{
${ }^{3}$ The relevance of the timing assumption can be easily assessed by comparing the results in this paper with those displayed in its preliminary version Christoffel et al. (2009a).
} 
where $\mathcal{U}_{t}$ represents the present value of being unemployed at period $t$ :

$$
\mathcal{U}_{t}=b+\mathrm{E}_{t}\left\{\beta_{t, t+1}\left[s_{t+1} \mathcal{W}_{t+1}+\left(1-s_{t+1}\right) \mathcal{U}_{t+1}\right]\right\}
$$

\subsection{Wage bargaining}

The outcome of the bargaining process is obtained by maximising the Nash product over wages and hours:

$$
\max _{w_{t}, h_{t}}\left(\mathcal{W}_{t}-\mathcal{U}_{t}\right)^{\eta}\left(\mathcal{J}_{t}-\mathcal{V}_{t}\right)^{1-\eta}
$$

The first term of the Nash product is the surplus a worker obtains from a job, raised to the worker's relative bargaining power $\eta \in(0,1)$. The second term is the firm's surplus, raised to the firm's relative bargaining power $1-\eta$.

The first-order condition for wage bargaining simplifies to

$$
\eta\left(\mathcal{J}_{t}-\mathcal{V}_{t}\right)=(1-\eta)\left(\mathcal{W}_{t}-\mathcal{U}_{t}\right)
$$

which states that each of the contracting parties receives a share of the total surplus proportional to its relative bargaining power. The first-order condition for hours worked yields

$$
\frac{\chi}{\lambda_{t}} h_{t}^{\phi}=x_{t} \alpha h_{t}^{\alpha-1}
$$

This shows that the wage paid in any individual match is not allocative for hours in existing matches, that is $\partial h_{t} / \partial w_{t}=0$. Note that $x_{t}$, the price of the intermediate goods, coincides with the marginal cost for price-setting firms. Rearranging we have

$$
x_{t}=\frac{\chi \frac{h_{t}^{\phi}}{\lambda_{t}}}{\alpha h_{t}^{\alpha-1}} \equiv \frac{m r s_{t}}{m p l_{t}} .
$$

This highlights that real marginal cost will equal the worker's marginal rate of substitution between consumption and leisure $\left(m r s_{t}\right)$ divided by the real marginal product of labour $\left(m p l_{t}\right)$. This makes clear that the subjective price of work determines the 
marginal wage, and the marginal cost of producing differentiated goods. Note that, in contrast, the average hourly wage rate, $w_{t}$, does not measure marginal costs in the above setup. The marginal cost here is determined by having an employed worker work for an additional hour, while the average wage rate averages over all hours worked (including the infra-marginal hours).

\subsection{Vacancy posting}

In order to find a worker, labour firms have to post a vacancy. Free entry in the market for vacancies implies that in equilibrium the value of a vacancy is $\mathcal{V}_{t}=0$ in every period $t$, so (13) yields

$$
\kappa=q_{t} \mathcal{J}_{t}
$$

\subsection{Monetary policy, fiscal policy and market clearing}

Monetary policy is conducted according to the following Taylor rule

$$
\hat{R}_{t}=\gamma_{r} \hat{R}_{t-1}+\left(1-\gamma_{r}\right) \gamma_{\pi} \hat{\pi}_{t-1}+\zeta_{t}^{m}
$$

where $\gamma_{r} \geq 0, \gamma_{\pi}>1$ and $\zeta_{t}^{m}$ is an i.i.d. interest rate shock. The Taylor rule that we use in this paper requires only lagged information, so the initial reaction of nominal rates to a monetary easing is the same in all the model variants that we discuss. Lumpsum taxes, $t_{t}$, are set so as to balance the budget period by period. Equilibrium in the final goods market implies $y_{t}=c_{t}{ }^{4}$

\section{Stylised facts and the baseline economy}

The aim of this paper is to elicit the role of specific labour market features for the behaviour of wages, employment and inflation. In order to do so, when going from

\footnotetext{
${ }^{4}$ Here, vacancy posting costs are taxes that are rebated lump-sum to the families and that do not require real ressources. This simplifies the comparability of the different modelling variants.
} 
one variant to the other, we do not alter the calibration. Rather, the calibration is harmonised across model variants.

\subsection{Calibration of the model economies}

The calibration largely follows Christoffel et al. (2009b) and matches salient features of the euro area between 1984 and 2006. Table 1 presents the assigned common parameter values.

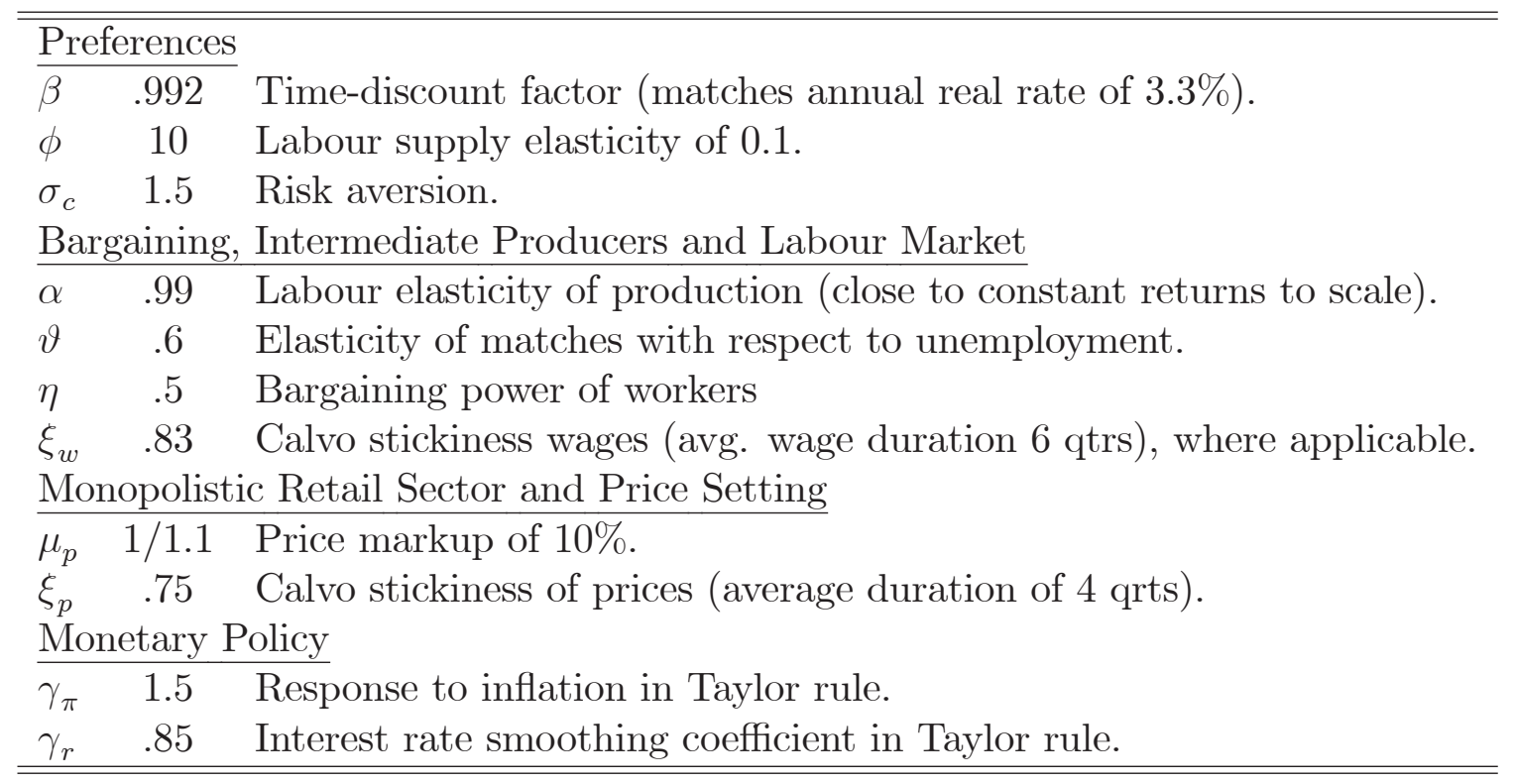

Table 1: Parameters and their Calibrated values. The table reports calibrated parameter values that are identical over the different modeling approaches.

The time-discount factor, $\beta$, is chosen to match an average annual real rate of $3.3 \%$. We set $\phi$ to 10 , implying an elasticity of substitution for labour of 0.1 , in line with microeconomic studies for the euro area. ${ }^{5}$ The value of the risk aversion coefficient is set to $\sigma_{c}=1.5$. Turning to the labour good sector and the labour market, we set $\alpha=0.99$, so there are almost constant returns to hours per employee. Petrongolo and Pissarides (2001) survey estimates of the matching function for European countries and for the United States and conclude that a range from $\vartheta=0.5$ to $\vartheta=0.7$ is admissible. We select the midpoint, setting $\vartheta=0.6$. The bargaining power of workers is set to a conventional value: $\eta=0.5$.

\footnotetext{
${ }^{5}$ The elasticity of inter-temporal substitution of labour, $1 / \phi$, is small in most microeconomic studies (between 0 and 0.5) for the euro area; for details, see Evers, Mooij, and Vuuren (2005).
} 
Some of the variants we consider later involve wage stickiness, for these we follow du Caju et al. (2008), who report an average wage contract duration in the euro area of between one and three years. We set the degree of nominal wage rigidity to $\xi_{w}=0.83$, which implies an average wage duration of 6 quarters. In the price-setting sector, we set the markup to a conventional value of $10 \%$, so $\mu_{p}=1 / 1.1$, implying a price-elasticity of demand of $\epsilon=11$. We set the corresponding Calvo parameter to $\xi_{p}=0.75$, which amounts to an average price duration of 4 quarters, in line with Alvarez et al. (2006). As is conventional, we set the response of monetary policy to inflation to $\gamma_{\pi}=1.5$ and allow for interest rate smoothing by setting $\gamma_{R}=0.85$.

Given these parameters, we set the other parameters of our models to ensure that the steady-state values for certain endogenous variables coincided across the different setups. The target values for these variables are shown in Table. 2. We normalize steady-state hours worked per employee to $h=1$.

\begin{tabular}{ccl}
\hline \hline & Value & Explanation \\
\hline$u$ & $9 \%$ & Unemployment rate \\
$q$ & $70 \%$ & Probability of finding a worker \\
$h$ & 1 & Hours worked per employee. \\
$\frac{b}{w h}$ & $65 \%$ & Unemployment benefits replacement rate. \\
$\rho$ & .06 & Quarterly separation rate. \\
\hline \hline
\end{tabular}

Table 2: Calibration TARgets. The table reports calibrated parameter values. The model is calibrated to the euro area from 1984Q1 to 2006Q4.

The steady-state unemployment rate is targeted to be the euro-area average of $u=9 \%$. The remaining targets follow the evidence collected in Christoffel et al. (2009b). The probability of finding a worker is $q=0.7$. The replacement income $b$ is set to ensure that the replacement rate, $\frac{b}{w h}$, equals $65 \%$, the average net replacement rate in the euro area. Finally, the quarterly separation rate is set to $\rho=6 \%$. 


\subsection{Stylised facts - the transmission of monetary policy}

In this section, we present some stylised facts for the transmission of monetary policy in the euro area. Figure 1 reports estimates of the effects of a monetary policy shock in the euro area using a structural VAR. The sample starts in 1984 Q1, and runs through 2006 Q4. The VAR(4) contains the variables shown in the graphs, together with a commodity price index. The monetary shock is identified by the oft-used recursive ordering scheme in which only commodity prices react to the monetary shock in the same quarter. Bounds are 90 percent confidence intervals. A monetary easing of 100 basis points (annualised) causes a significant increase in output, and an increase in real wages per employee of about half that size. According to our estimates, the unemployment rate drops by about 0.5 percentage points, corresponding to a fall in the number of unemployed workers of about $5 \%$. At the same time, the increase in inflation remains contained, with GDP deflator inflation running at around 0.4 percentage points in annualised terms. The results also suggest that the intensive margin shows only a small response to the monetary shock, and so most of the adjustment is borne by the number of employees rather than by hours per worker. Since average hours per worker are not so volatile, most of the literature has focussed on the extensive margin and ignored adjustment in hours. However, since hours can be adjusted (and are, especially in manufacturing) in the short run, it would seem important to try and match endogenously the relative responses of hours and employment to shocks within the model. ${ }^{6}$

Table 3 summarises the impulse responses reported above. In order to give the reader a feel for the sensitivity of our results, we augment this with evidence from four further studies for the euro area. McCallum and Smets (2008) estimate a factor-augmented VAR. Angeloni et al. (2003) report impulse responses for the euro area based on var-

\footnotetext{
${ }^{6}$ The confidence bands around the response of hours per worker likely understate the true uncertainty surrounding that response since estimates of actual hours worked for the euro area involve measurement problems. Harmonized quarterly series for hours worked do not exist for the euro area, or even for all its member countries individually. In the above estimation, we resorted to the same proxy for hours worked in the euro area that was previously used by Christoffel et al. (2009b). This proxy uses the quarterly real GDP series for the euro area to interpolate annual EU-Klems data on total hours worked in the euro area.
} 


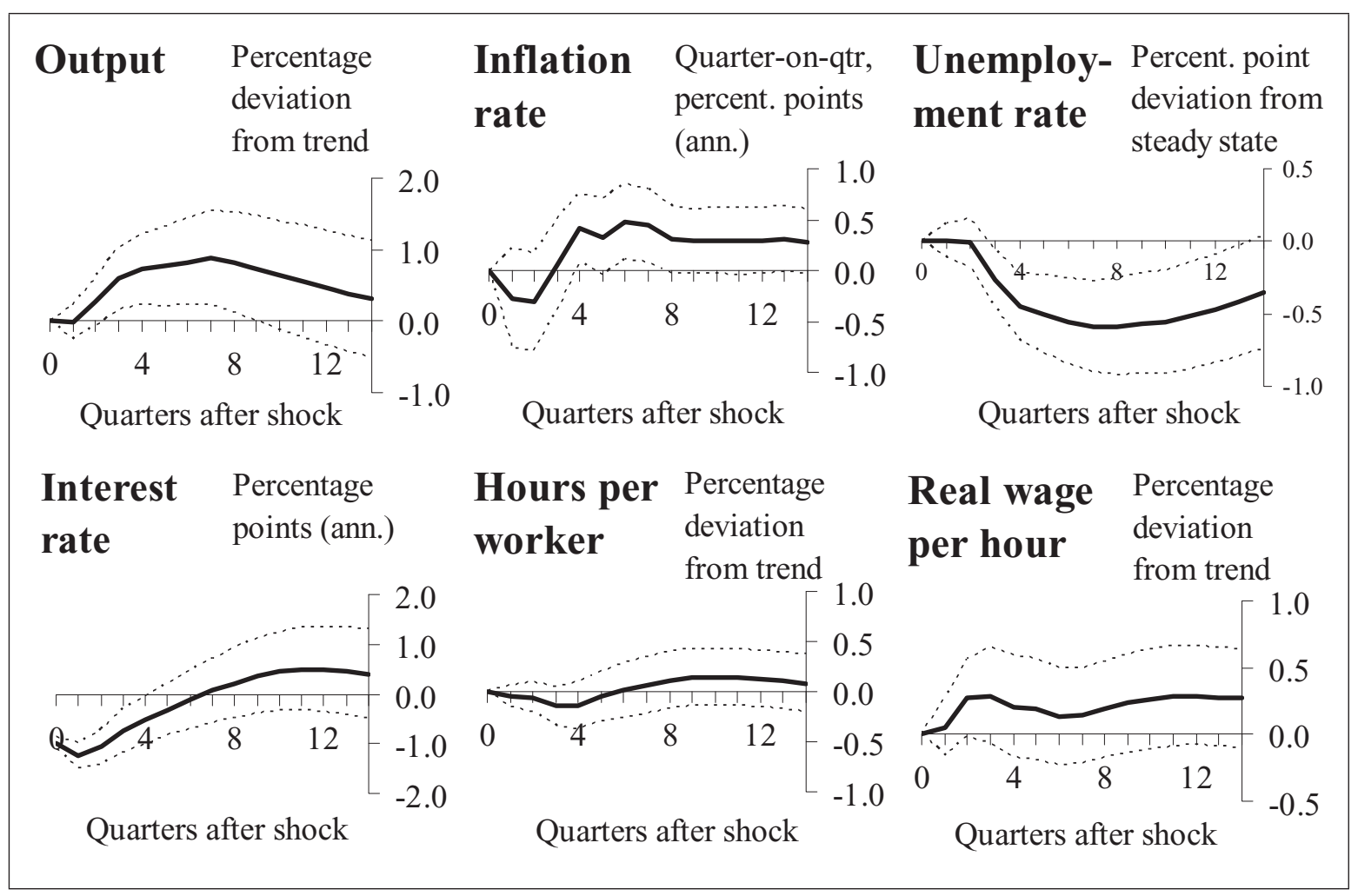

Figure 1: IMPULSE RESPONSES TO AN UNANTICIPATED MONETARY SHOCK. Underlying the results is a $\operatorname{VAR}(4)$ estimated on above data plus commodity prices (taken from the AWM data set except for hours worked, which is taken from Christoffel et al., 2009). The sample is 1984 Q1 to 2006Q4; identification relies on the usual Cholesky decomposition. The data were de-trended variable by variable prior to running the VAR. For real variables, we allow for a trend, a break in the trend and a level shift in 1991Q1 so as to accommodate German reunification. Inflation and nominal interest rates were regressed on a linear trend, which breaks after 1998Q4 in order to account for the disinflation in the euro area prior to the introduction of the common currency, and the constancy of the inflation objective thereafter. Dotted lines mark asymptotic $90 \%$ confidence intervals ( $5 \%$ and $95 \%$ bounds). 
ious identification schemes in a standard VAR. So do Peersman and Smets (2003). Peersman and Straub (2007) identify responses to a monetary shock based on sign restrictions derived from a New Keynesian model. The table summarises the maximum amplitudes of the variables following the monetary shock.

\begin{tabular}{l|ccccl}
\hline Study & Output & $\begin{array}{l}\text { Inflation } \\
\text { (pp. annu- } \\
\text { alised) }\end{array}$ & $\begin{array}{l}\text { Unem- } \\
\text { ploym. } \\
\text { rate (pp) }\end{array}$ & $\begin{array}{l}\text { Real wage Hours per } \\
\text { per hour }\end{array}$ & $\begin{array}{l}\text { worker } \\
\text { rated }\end{array}$ \\
\hline \hline$(1)$ & 0.7 & 0.4 & -0.47 & 0.2 & 0.1 \\
$(2)$ & 0.7 & 0.2 & -0.26 & - & - \\
$(3)$ & 0.4 & 0.3 & -0.21 & 0.2 & 0 \\
$(4)$ & 0.5 & 0.2 & -0.30 & - & - \\
$(5)$ & 0.4 & 0.2 & -0.26 & - & - \\
\hline \hline
\end{tabular}

Table 3: MAXimum Responses to A MONEtary EASING IN THE Literature. Most of the studies imply that after the initial easing, nominal rates fall somewhat further before they tighten. All responses have been normalized by the respective maximum easing of the nominal interest rate. Figures reported refer to maximum of the median response. (1): Our VAR, as described in the main text. For the other studies, results were read off the figures and tables. (2): McCallum and Smets (2008). Sample: 1987Q1 to 2005Q4. The response for the unemployment rate is inferred from the figure for employment assuming a constant labor force and an average unemployment rate of 9\%. (3): Peersman and Straub (2007) only report the response of total hours worked but state that responses are similar when employment is used. We infer that hours per worker are not much affected. The response for the unemployment rate is inferred as in (2). (4): Peersman and Smets (2003): sample 1980-1998. Entries are based on their Fig. 2.1 and Fig. 2.8. The response for the unemployment rate is inferred as (2). (5): Angeloni et al. (2003) report the response of the unemployment rate (see their Table 6). Results for the Angeloni et al. paper are averages over different specifications for the sample 1980-2000.

We summarize the above discussion in five stylised facts. In response to a monetary shock that causes interest rates to fall by 100 basis points in annualised terms, empirical evidence suggests that in the euro area:

Fact 1: output rises significantly above its steady state. Depending on the study the peak response varies between 0.4 and 0.7 per cent.

Fact 2: inflation rises. The peak increase in year-on-year inflation lies between 0.2 and 0.4 percentage points.

Fact 3: real wages per hour also rise but by less than output.

Fact 4: unemployment falls significantly, by $2.5 \%$ to $5 \%$ (number of heads), and the unemployment rate falls by 0.2 to 0.5 percentage points. 
Fact 5: most of the adjustment in labour is borne by the number of employees rather than by hours worked per employee. Some uncertainty surrounds this statement, though, due to the limited quality of the euro-area data for hours worked.

While significant differences exist in the microstructure of the economy, and the labour market in particular, between the euro area and the United States, the above stylised facts happen to be consistent also with the evidence for the United States, e.g., Christiano et al. (2005), Angeloni et al. (2003) and Trigari (2009). In the following, we assess each of the different modeling variants against these five stylised facts. ${ }^{7}$

\subsection{Effects of a monetary policy shock in the baseline}

Figure 2 reports the response of the model economy to a monetary easing. Inflation and real wages respond far too strongly to the monetary easing (by a factor of ten) while output effects are of the right size. Average hours respond too strongly and employment not strongly enough. The strong response of inflation comes from the fact that real marginal costs for price-setting firms are largely determined by the cost of increasing hours worked by each worker. Under efficient bargaining, the baseline case, these marginal costs are given by the marginal rate of substitution divided by the marginal product of labour, $x_{t}=\frac{m r s_{t}}{m p l_{t}}$. Given near constant returns to scale ( $\alpha$ close to unity), the marginal product of labour, $m p l_{t}$, will be little affected by the shock. The percentage change in real marginal cost will therefore be driven by the response of the marginal rate of substitution, $m r s_{t}$. This in turn depends on the percentage change in the marginal utility of consumption and, more fundamentally, on the response of hours per worker, where the latter is amplified $\phi$ times. This implies a strong response of real marginal cost to an increase in hours worked and output. ${ }^{8}$

\footnotetext{
${ }^{7}$ For the sake of exposition, we do not force the models to obey the same identifying assumptions as in the VAR. It is well-known that accounting for the one-period lag between interest rates and inflation would not materially change the responses going forward.

${ }^{8}$ As Trigari (2006) highlights, if more of the labour adjustment needed to produce the additional output is provided through the extensive (number of employees) margin, the intensive (hours per employee) margin will also react less, which curbs the rise in the marginal rate of substitution and thus the rise in marginal costs.
} 


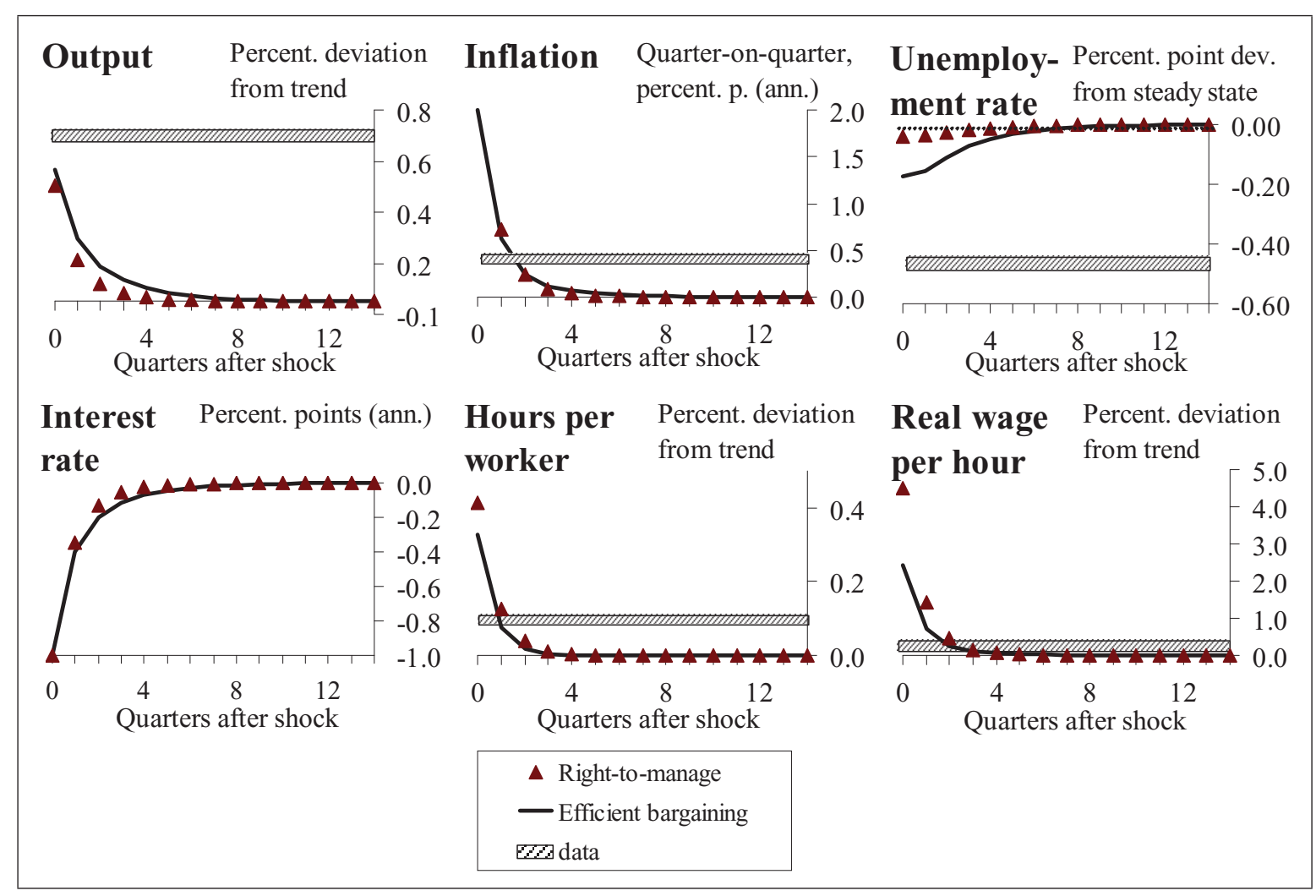

Figure 2: Impulse Responses to A MONETARY EASING - EFFicient BARGAining BASELINE AND RIGHT-TO-MANAGE. Shown are impulse responses to an unanticipated 100 bps reduction in the quarterly nominal interest rate in quarter 0. Output, hours and real wages per worker are in percentage deviations from steady state. Unemployment rates, interest rates and inflation rates are in percentage point deviation from steady state. Inflation and interest rates are quarterly, reported in annualized terms. The black solid line shows the responses in the efficient bargaining baseline; see Section 3.3. The red triangles show the responses under right-to-manage bargaining; see Section 4.1. Shaded areas mark the peak responses in our VAR, cf. Figure 1. 


\section{Assessing other modeling variants}

Given the weaknesses of the baseline model with respect to the responses of employment, hours worked and inflation, several modifications of the model have been proposed by the literature. This section assesses the performance of many of these model variants. We start by altering the bargaining scheme, and by allowing for wage stickiness. Thereafter, we touch on the separation between wage and price setting, assess an alternative specification of vacancy posting costs, look at search on-the-job and endogenous separation.

\subsection{Varying the bargaining scheme: right-to-manage}

In this section, we follow Trigari (2006) and use a 'right-to-manage' (RTM) assumption for the bargaining process. In this setup, the wage rate is agreed upon first. Then the firm chooses hours worked at that wage rate so as to maximise profits.

The same wage rate applies to marginal and inframarginal hours worked. This setting preserves much of the empirically successful structure of the New Keynesian model. ${ }^{9}$

The first-order condition for labour demand is:

$$
x_{t} \alpha h_{t}^{\alpha-1}=w_{t} .
$$

In principle, the RTM assumption radically modifies the composition of real marginal cost. Under RTM, the hourly wage becomes an essential element of real marginal cost, as (22) implies $x_{t}=\frac{w_{t}}{m p l_{t}}$, reopening the wage channel to inflation; see Christoffel et al. (2009b) and Trigari (2006). ${ }^{10}$ The major difference to the efficient bargaining assumption is that the choice of hours depends directly on the average wage, and that

\footnotetext{
${ }^{9}$ Following Erceg et al. (2000), when modeling wage rigidities the literature typically assumes that monopolistically competitive labour firms produce an intermediate labour good. The assumption is that these firms set wages (the equivalent to the wage rate here) in a staggered manner and let labour output and thus input of hours into labour-good production (the equivalent to hours per employee here) be demand-determined.

${ }^{10}$ This does not, of course, mean that the marginal rate of substitution plays no role in inflation dynamics under right-to-manage in equilibrium. There is still an indirect influence of the marginal rate of substitution on inflation through its effect on the bargained wage.
} 
$\partial h_{t} / \partial w_{t}<0$. This affects the wage bargaining. Wage equation (17) becomes

$$
\eta \Omega_{t}\left(\mathcal{J}_{t}-\mathcal{V}_{t}\right)=(1-\eta)\left(\mathcal{W}_{t}-\mathcal{U}_{t}\right)
$$

with

$$
\Omega_{t}=\frac{1}{1-\alpha}\left(\frac{m r s_{t}}{x_{t} m p l_{t}}-\alpha\right)=\frac{1}{1-\alpha}\left(\frac{\chi h_{t}^{1+\phi-\alpha}}{\alpha \lambda_{t} x_{t}}-\alpha\right) .
$$

Equations (23) and (24) suggest that the worker's implicit bargaining power increases with hours worked. Therefore, if labour supply at the intensive margin is inelastic $(\phi$, is large enough), the average wage will tend to be more responsive under RTM than under efficient bargaining, curbing hiring incentives. It is less clear, however, whether this also implies that marginal costs are more responsive. Under RTM, the marginal wage coincides with the average wage, $w_{t}$, while under efficient bargaining the marginal wage is given by $m r s_{t}$, which in turn is more responsive than the average wage.

Figure 2 compares the response of the economy to a monetary shock under both bargaining schemes. As the above logic suggests, the average hourly wage rate, $w_{t}$, responds more strongly (and in fact much too strongly) to a monetary easing under RTM. Still, the marginal cost of firms and, thus, inflation move similarly under both bargaining schemes. We conclude that the bargaining scheme in itself has little implication for inflation dynamics. As the next section shows, however, different bargaining schemes can imply fundamentally different effects of different types of wage rigidity on inflation dynamics. Where the bargaining schemes differ is with regard to the response of unemployment. Due to the higher bargaining power implied by RTM, and the associated stronger increase in the real wage, hiring incentives are smaller than under efficient bargaining, moving the response of unemployment further away from its response in the data.

\subsection{Wage rigidity instead of period-by-period bargaining}

A cornerstone of the canonical New Keynesian framework is that average wage rates and wage stickiness are instrumental for inflation dynamics; see, e.g., Christiano et 
al. (2005). This section of the paper discusses the role of wage stickiness for inflation dynamics once we account for search and matching frictions in the labour market. The related New Keynesian literature is Trigari (2006), Christoffel and Linzert (2005), Christoffel and Kuester (2008), and Krause and Lubik (2007).

In the model, the role of wage stickiness for inflation dynamics depends on the type of wage bargaining (efficient vs. RTM) as well as on whether wage stickiness affects only existing matches or also new matches (and thus hiring incentives of firms). We assume that in each period only a fraction $\left(1-\xi_{w}^{o}\right)$ of all existing (old) wage contracts is renegotiated. New hires are paid either the existing nominal contract wage from the previous period (with probability $\xi_{w}^{n}$ ) or they freely negotiate the wage (with probability $\left.1-\xi_{w}^{n}\right)$. The asset value of a job clearly depends on the bargained wage. Adopting the viewpoint of an intermediate producer, we denote by $\mathcal{J}_{t}\left(w_{t-j}^{*}\right)$ the asset value in period $t$ of a job with a wage that was bargained $j$ periods ago. Ex ante, the asset value of a new match for the firm can be written as

$$
\mathcal{J}_{t}=\left(1-\xi_{w}^{n}\right) \mathcal{J}_{t}\left(w_{t}^{*}\right)+\xi_{w}^{n} \mathcal{J}_{t}\left(w_{t-1}\right)
$$

where $w_{t}$ is the average real wage in the economy. The asset value of a vacant job $\mathcal{V}_{t}$ is still given by equation (13); i.e., the vacancy posting condition is not modified.

\subsubsection{Efficient bargaining}

Under efficient bargaining, as we showed earlier, real marginal cost will equal the workers' marginal rate of substitution divided by their marginal product and will be independent of the average wage rate in existing matches. ${ }^{11}$ For that reason, wage rigidity only has a bearing on inflation dynamics if it affects the wages of prospective new hires. As Hall (2005) notes, wage stickiness in new matches enhances the cyclicality of job creation by altering the share of revenue left to firms. In response to a monetary

\footnotetext{
${ }^{11}$ The reason is that in existing matches the average wage rate is not allocative but rather splits the surplus of the match among the two parties. In particular, even when fixing the average hourly wage rate, this does not fix the hourly wage rate schedule. As part of an efficient bargaining agreement, the relevant section of marginal wages can be freely set in a state-contingent way even if average wage rates are fixed.
} 
easing, this means that firms make more recourse to the hiring margin instead of the intensive margin. As a result, the average worker works fewer hours than in the absence of wage stickiness. This means that the marginal rate of substitution rises less strongly and also that the marginal product of labour falls by less. As a result, wage stickiness for new hires, through its effect on employment, makes marginal costs (and thus inflation) less responsive to a monetary easing. ${ }^{12}$ Noteworthy, if wage stickiness affects only incubent workers $\left(\xi_{w}^{o}>0\right.$ and $\left.\xi_{w}^{n}=0\right)$, employment cyclicality would not be affected at all and all variables apart from the wage would behave exactly as in the benchmark.

Figure 3 quantifies this. With wage stickiness in both old and new matches, employment reacts much more strongly, indeed approaching the empirical evidence (see the red triangles relative to the solid baseline response with flexible wages). This leads to a quicker fall in the response of hours, and dampens the response of marginal cost and inflation. However, the improvement in the inflation response is still insufficient to match the stylised facts.

\subsubsection{Right-to-manage bargaining}

Section 4.1 highlighted that RTM implies a close relationship between hours worked and wages, and between inflation and wages. With the introduction of wage stickiness, as is clear from equation (22), optimal hours worked for the firm will depend on the bargained wage which can now differ from firm to firm.

Figure 3 shows the response to a monetary easing in the RTM model for two alternative assumptions regarding which wages are affected by nominal wage rigidity: The green squares show the case when both the wages of existing workers and new hires are sticky. The blue circles show the case when only the wages in existing matches are sticky. Two observations are in order. First and foremost, the combination of RTM bargaining with nominal wage stickiness produces sizable real rigidity, and thus a much weaker inflation

\footnotetext{
${ }^{12}$ See also Trigari (2006). Krause and Lubik (2007) find that wage stickiness is irrelevant for inflation dynamics. This rests on their assumption that there is only an extensive margin, in which case marginal costs are less affected.
} 


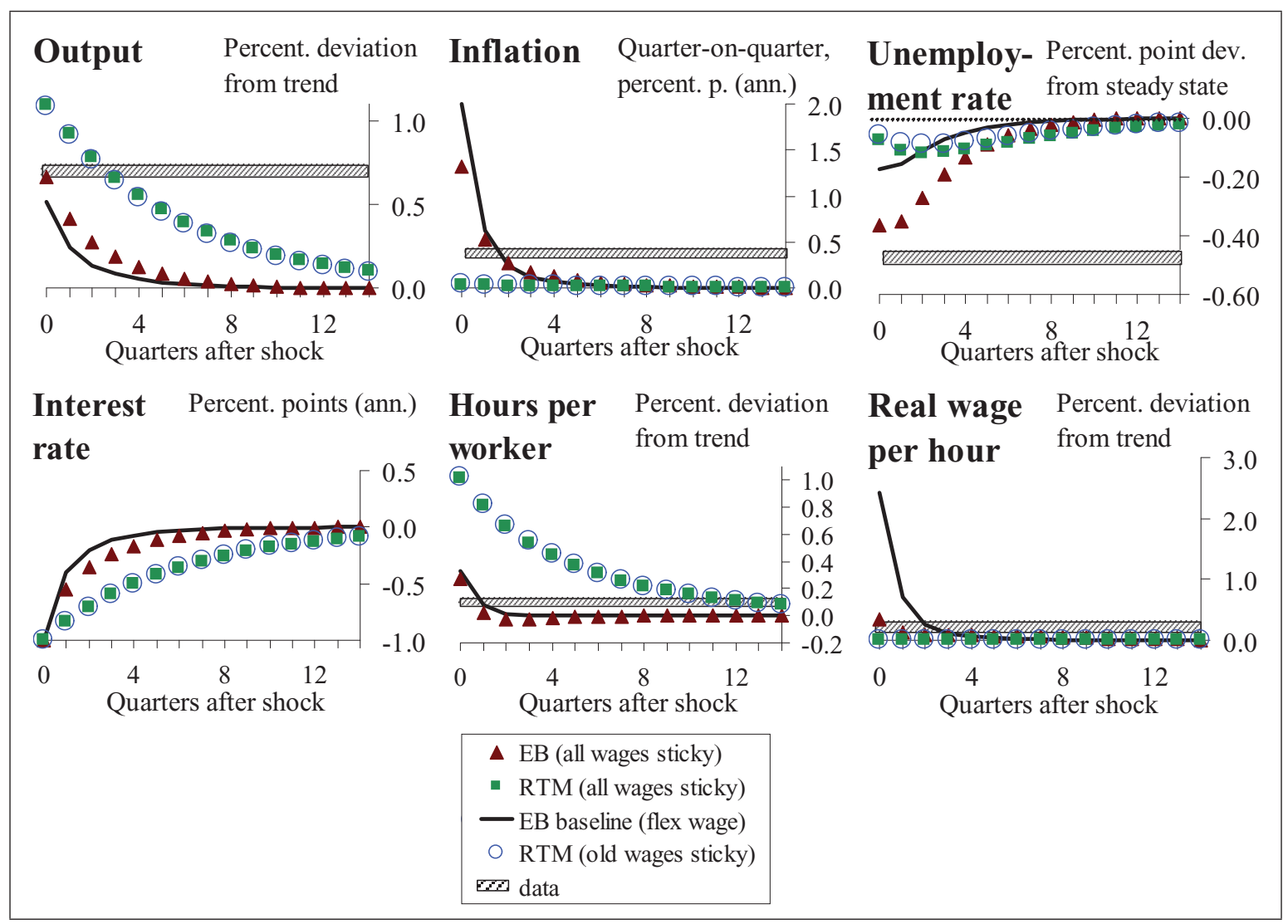

Figure 3: Impulse Responses to A MONETARY EASING - EFFicient Bargaining AND Right-TO-MANAGE, WAGE STICKINESS AND BASEline. Shown are impulse responses to an unanticipated 100 bps reduction in the quarterly nominal interest rate in quarter 0. Output, hours and real wages per worker are in percentage deviations from steady state. Unemployment rates, interest rates and inflation rates are in percentage point deviation from steady state. Inflation and interest rates are quarterly, reported in annualized terms. The black solid line shows the responses in the efficient bargaining baseline (flexible wages); see Section 3.3. The red triangles show the responses under efficient bargaining when wages of new hires and of existing hires are sticky; see Section 4.2.1. For the same assumption on wage stickiness, the green squares show the responses under RTM. The blue circles mark the responses under RTM when wages of new hires are flexible, and only the wages of existing hires are sticky; see Section 4.2.2. Shaded areas mark the peak responses in our VAR, cf. Figure 1. 
response, owing to the wage channel that is present in that model variant. Second, the responses are very similar for the two cases of wage rigidity. Whether wage rigidity affects only existing matches, or all matches, does not matter much neither for inflation dynamics nor for employment. (See also Christoffel and Kuester (2008).) But, there are two downsides. First, the real rigidity is actually too strong in this case. Second hours per worker remain far too responsive relative to the data, since unemployment does not respond by enough.

\subsection{Varying the market structure: real rigidities arising within the individual firm}

This section emphasises real rigidities arising at the individual firm level over and above the real rigidities arising at the aggregate level that we emphasized previously. ${ }^{13}$ The presence of search and matching frictions in the labour market means that a worker in this economy temporarily constitutes a factor of production specific to the firm at which she is employed. If wage and price setting occurs in the same firm, as in Kuester (2007), this means that the price setting internalizes the effect it has on wages. ${ }^{14}$ The mechanism at work is the following. A firm that can re-optimise its price passes part of any cost increase on to the consumers. The demand for its product falls. If workers have an increasing marginal disutility of work, the associated fall in hours worked leads to a reduction in the worker's marginal disutility of work and his marginal wage, which counterbalances the original increase in costs. Therefore price-setting firms move prices by less than in the baseline model for any given increase in aggregate marginal costs. This intuition is borne out in the New Keynesian Phillips curve for the modified model

\footnotetext{
${ }^{13}$ For real rigidities arising at the aggregate level prices (and thus inflation) will respond the less to shocks the less (the aggregate component of) marginal cost responds to these shocks. For real rigidities arising at the individual firm level, prices will respond the less to shocks the more (the firm-specific component of) any firm's marginal cost rises with demand. For a further exposition, see Woodford (2003, Chapter 3).

${ }^{14}$ In the intermediate labor sector of the baseline model, workers also constituted a temporarily firmspecific production factor. By assumption, however, this sector operated under perfect competition and flexible prices for the intermediate good.
} 
economy:

$$
\widehat{\pi}_{t}=\beta(1-\rho) E_{t}\left\{\widehat{\pi}_{t+1}\right\}+\frac{1-\xi_{p}}{\xi_{p}}\left[1-\beta(1-\rho) \xi_{p}\right]\left\{\frac{1}{1+\frac{\epsilon}{\alpha}[(1-\alpha)+\phi]}\right\} \widehat{x}_{t .}
$$

With respect to the baseline, equation (7), there is an additional term dampening the pass-through of marginal cost on inflation (underlined). The more price-elastic is demand (the larger is $\epsilon=1 /\left(1-\mu_{p}\right)$ ), the more curved is the marginal disutility of labour (the larger is $\phi$ ) and the faster the returns to hours per employee decrease at the firm level (the smaller is $\alpha$ ), the less will firms adjust prices to aggregate shocks, and therefore the weaker will be the response of inflation to its aggregate driving forces. As a result, inflation reacts considerably less to the monetary shock when allowing for firm-specific labour, bringing the response more in line with the stylised facts (see the red triangles in Figure 4). In turn, this implies that the monetary easing provides more stimulus, which translates into a response of output that is larger than in the baseline. On the downside, however, the unemployment response is far too weak. The firms' surplus from a job is bigger than in the baseline, since it includes the positive profits that arise in the production of the differentiated goods. In addition, profits associated with jobs now have two components: one coming from the job/match surplus proper as in the previous models, and the other one coming from the markup that firms charge. The latter component tends to contract, however, in the wake of a monetary easing. Therefore, the response of unemployment is weaker than in the baseline, and consequently the response of hours worked is stronger, moving both of these responses farther away from the data.

\subsection{Varying the vacancy posting condition}

How vacancy creation moves over the business cycle is essential for determining the response of the intensive vs. the extensive margin of labour adjustment. As discussed in Section 3.3, this in turn has a bearing on the response of marginal wages, marginal cost and inflation over the business cycle. In the RBC literature several modifications of the 


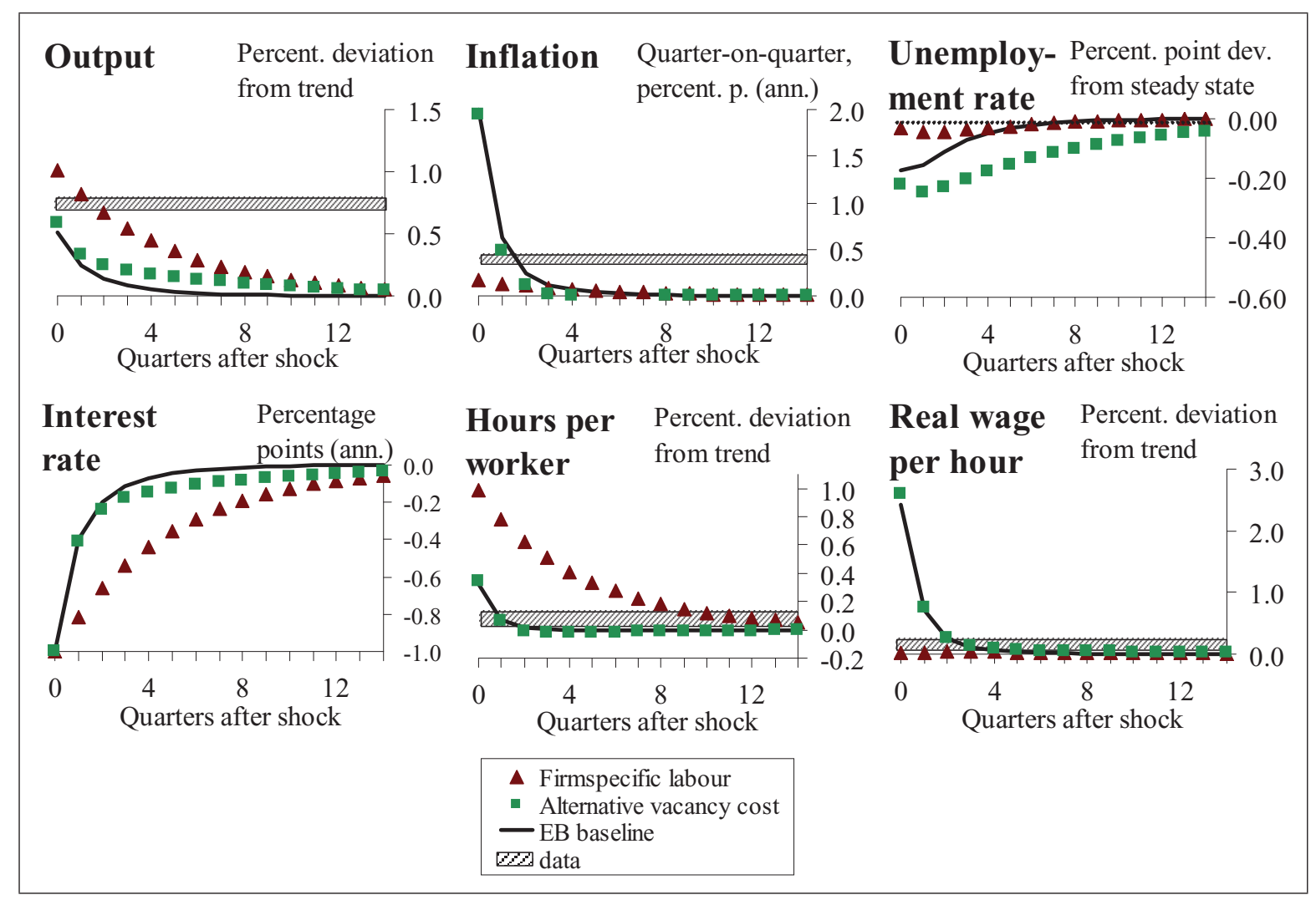

Figure 4: Impulse Responses to A MONETARY EASING - Firm-SPECifiC LABOur, CONVEX VACANCY COSTS AND BASELINE. Shown are impulse responses to an unanticipated 100 bps reduction in the quarterly nominal interest rate in quarter 0 . Output, hours and real wages per worker are in percentage deviations from steady state. Unemployment rates, interest rates and inflation rates are in percentage point deviation from steady state. Inflation and interest rates are quarterly, reported in annualized terms. The black solid line shows the responses in the efficient bargaining baseline. The red triangles show the responses when the price and wage-setting sectors are merged (firmspecific labour); see Section 4.3. The green squares show the responses when costs per hire are proportional to the hiring rate (alternative vacancy cost); see Section 4.4. Shaded areas mark the peak responses in our VAR, cf. Figure 1. 
vacancy posting process have been introduced with the aim of helping the Mortensen and Pissarides model reproduce labour market stylised facts. Here we extend the analysis to inflation dynamics. Following Yashiv (2006) and Gertler and Trigari (2006), we drop the assumption of a fixed recurrent vacancy posting cost, replacing $\kappa$ in (20) by $\kappa_{t} . \kappa_{t}$ is defined such that the cost per hire, $\kappa_{t} / q_{t}$ is now proportional to the hiring rate, $\frac{m_{t}}{n_{t}}, 15$

$$
\frac{\kappa_{t}}{q_{t}}=\psi \frac{m_{t}}{n_{t}}, \psi>0
$$

The rationale for this way of modelling is in understanding a match as one job in a large, multi-worker firm. The reason why costs per hire decrease with employment is that more employment eases the integration of new hires. This is in contrast to the baseline where the cost per hire typically increases with employment, $n_{t}$, due to the congestion effect associated with the search and matching process. All else equal, this will lead to greater variation in employment and thus less variation in marginal costs and inflation.

Indeed, at the calibrated parameter values, Figure 4 shows that hiring reacts more strongly to shocks relative to the baseline, so unemployment falls more strongly (see green squares). Therefore hours worked and marginal costs react less strongly, which reduces the effect of the monetary easing on inflation. Quantitatively, however, in our calibration the effect is not big. ${ }^{16}$

\subsection{Allowing for additional worker flows: On-the-job search and endogenous separation}

This section alters the baseline model by allowing for additional directions of worker flows. We first allow for job-to-job transitions by means of search on-the-job. We then assess endogenous separations.

\footnotetext{
${ }^{15}$ Parameter $\psi$ is calibrated such that the targets in Section 3.1 are satisfied.

${ }^{16} \mathrm{We}$ also looked at the formulation of Fujita and Ramey (2007), which assumes that vacancies remain active until they are filled. Apart from making vacancies more persistent, this had little effect on the other model variables dynamics.
} 


\subsubsection{On-the-job search}

This section alters the baseline model by allowing for job-to-job transitions by means of search on-the-job. In the baseline only unemployed workers can search, with the result that only they enter the matching function and can be matched up with vacancies. But, in reality, job-to-job movements form a large part of worker flows and are, thus, potentially important for employment, wages and marginal costs over the cycle. This section follows the modeling of Krause and Lubik (2006) and van Zandweghe (2009). Jobs come in two types: 'good' jobs (that are more productive) and 'bad' jobs. Aggregate output is produced using workers employed in both types of jobs. The presence of two types of jobs creates an incentive for workers employed in bad jobs to search for good jobs. The relevant measure of labour market tightness for the 'good' sector is now $\frac{v_{g, t}}{\rho n_{g, t-1}+e_{t}}$, where $v_{g, t}$ is the number of vacancies advertised in the 'good' sector, $n_{g, t}$ is the number of workers employed in the good sector and $e_{t}$ is the number of employed searching workers. ${ }^{17}$ Since $e_{t}$ will be procyclical, fluctuations in labour market tightness will be dampened and this holds down the cost of employment adjustment: effectively flattening the aggregate supply curve. In other words, the extra margin of employment adjustment adds a real rigidity to the model, which we would expect to dampen the response of inflation to nominal shocks.

Differentiated goods are produced using a Cobb-Douglas function of labour input in each of the two qualities. So real marginal cost will be given by:

$$
x_{t}=\left(\frac{x_{g, t}}{1-\omega}\right)^{1-\omega}\left(\frac{x_{b, t}}{\omega}\right)^{\omega}
$$

where $\omega$ denotes the share of the output of 'bad' jobs in final output and $x_{j, t}$ denotes real marginal cost in sector $j .{ }^{18}$ With efficient bargaining over hours, real marginal cost

\footnotetext{
${ }^{17}$ We assume that when workers are laid off, they can search next period for jobs in the same sector. After that, unemployed workers all look for jobs in the 'bad' sector, regardless of where they previously worked. We also make the simplifying assumption that all employed workers in bad jobs search for good jobs (with unit search intensity). This reduces the cyclicality of employed search relative to the model of van Zandweghe (2009) since, in his model, 'search intensity' was procyclical, along with the number of searching workers.

${ }^{18}$ Following Krause and Lubik (2006), we set $\omega$ to 0.4 and calibrated the model so as to generate a job-to-job transition (quit) rate of $6 \%$. Finally, we assumed that hiring costs in the 'good' sector are three times as large as those in the 'bad' sector. All other parameters were set to the same values as
} 
in each sector will again be equal to the marginal rate of substitution divided by the marginal product of labour for workers employed in that sector: $x_{g, t}=m r s_{g t} / m p l_{g t}$ and $x_{b, t}=m r s_{b t} / m p l_{b t}$. This is a key difference between our model and those of Krause and Lubik (2006) and van Zandweghe (2009), which both only allow for adjustment on the extensive margin.

Figure 5 shows that with on-the-job search, the response of unemployment and hours worked moves closer to the data. As a result, the response of inflation is somewhat attenuated relative to the baseline (see red triangles). The reduction in the response of inflation is considerably less though than in van Zandweghe (2009). The reason is that in our model, hours are allowed to adjust to shocks. This reduces the degree of real rigidity in the model and means that movements in real marginal cost are not dampened as much relative to the baseline as they are in his work.

\subsubsection{Endogenous separation}

While we simplified our baseline model by assuming jobs separate at a fixed rate, in reality separation is an endogenous choice of the matched worker-firm pair, and the separation rate is strongly negatively correlated with hiring. This suggests that we should check how our model behaves when we endogenize the separation margin simultaneously with the other margins of labour market adjustment. Moreover, variable separation may serve as another source of unemployment volatility, as in Mortensen and Nagypal (2007); and if we model separation like Mortensen and Pissarides (1994) by assuming matches are subject to idiosyncratic productivity shocks, this may affect productivity and marginal cost dynamics; see also Trigari (2009). Therefore, in this section we suppose that the income produced by a match is $x_{t} z_{i t} h_{i t}^{\alpha}$, where $z_{i t}$ is a productivity component specific to match $i$. We will assume $z_{i t}$ is log-normally distributed with a cumulative distribution $F$, with mean 1 and standard deviation $\sigma_{z}$. The reservation productivity at which separation occurs is called $\underline{z}_{t}$.

Following den Haan et al. (2000), we assume $z_{i t}$ is uncorrelated with aggregate shocks, in the baseline model. 


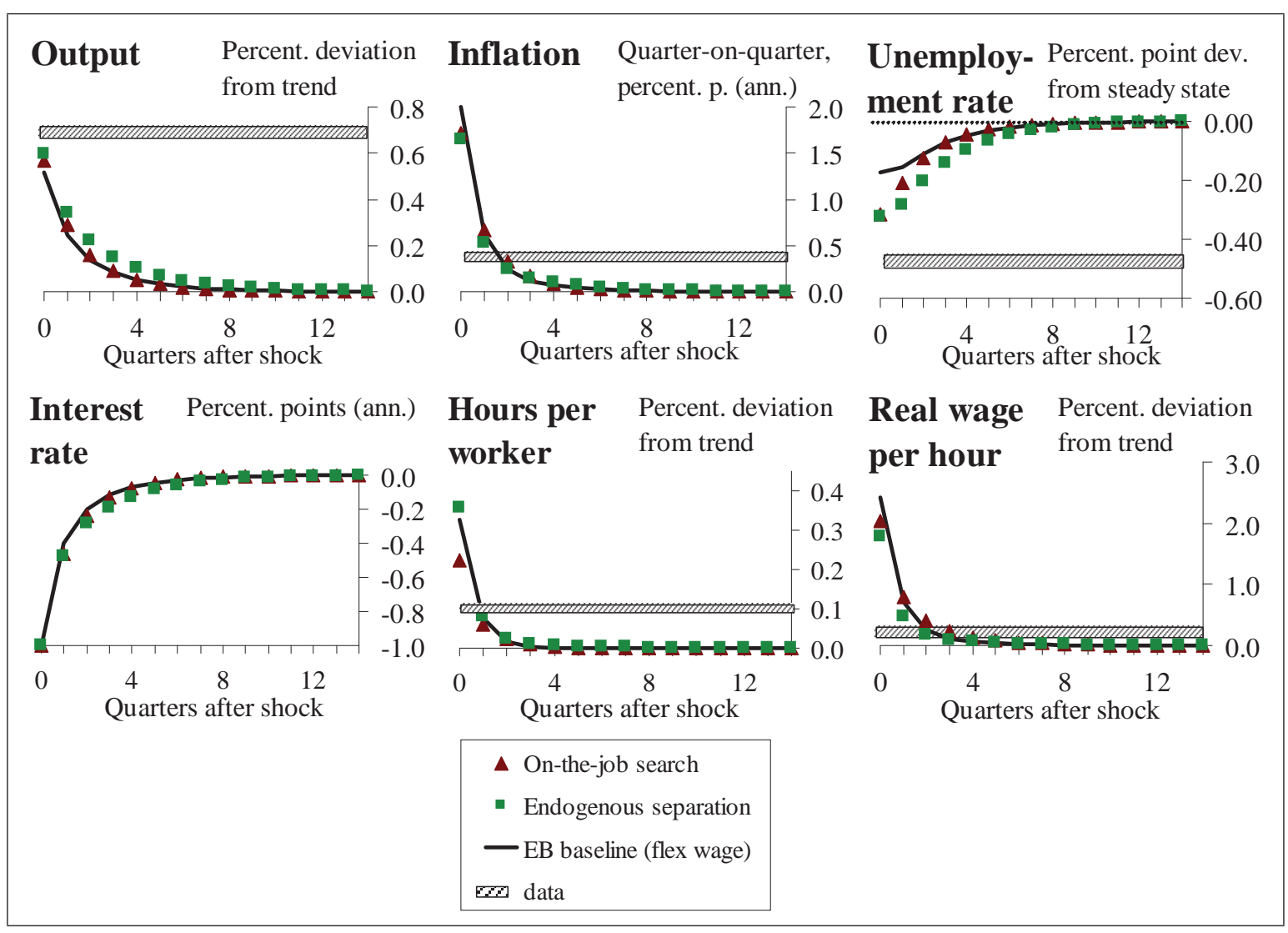

Figure 5: Impulse Responses to a monetary EAsing - On-the-Job SEARCh, ENDOGENOUS SEPARATION, AND BASELINE. Shown are impulse responses to an unanticipated 100 bps reduction in the quarterly nominal interest rate in quarter 0 . Output, hours and real wages per worker are in percentage deviations from steady state. Unemployment rates, interest rates and inflation rates are in percentage point deviation from steady state. Inflation and interest rates are quarterly, reported in annualized terms. The black solid line shows the responses in the efficient bargaining baseline. The red triangles show the responses in the model with on-the-job search; see Section 4.5.1. The green squares show the responses in the model with endogenous separation; see Section 4.5.2. Shaded areas mark the peak responses in our VAR, cf. Figure 1. 
uncorrelated across individual matches $i$, and uncorrelated over time. At the end of each period some existing matches separate for exogenous reasons with probability $\rho^{x}$. Employment dynamics therefore are now given by:

$$
n_{t}=\left(1-F\left(\underline{z}_{t}\right)\right)\left[\left(1-\rho^{x}\right) n_{t-1}+m_{t}\right]
$$

and the fraction of jobs surviving from $t-1$ to $t$ is $1-\rho_{t}=\left(1-F\left(\underline{z}_{t}\right)\right)\left(1-\rho^{x}\right)$. As in the baseline, we assume the matching function is given by (8), the search pool is given by $u_{t}^{s}=u_{t-1}+\rho^{x} n_{t-1}$, and bargaining is efficient, so that (18) determines hours $h\left(z_{i t}\right)$ as a function of idiosyncratic productivity. Then, if we interpret the endogenous component of separation as the part driven by changes in firms' demand for specific types of labour in specific establishments, and the exogenous component as separations driven by worker demographics, we can use calculations from Davis, Haltiwanger and Schuh (1996, Chapter 2.5) to calibrate these two components. For the United States, they compare firm-level job destruction (which at quarterly or annual frequencies they argue should reflect changes in firms' labour demand only) with total worker separation flows (which are larger and include worker-initiated changes in employment status). They find that the demand-driven component is roughly $40 \%$ of the total, which - absent evidence for the euro area - is the number we use here. Then for any standard deviation $\sigma_{z}$ of the idiosyncratic shock, we can calculate $\underline{z}=F^{-1}(0.4 \cdot 0.06)$, assuming $6 \%$ total separation flows as before. When we set the standard deviation of the idiosyncratic shock to $\sigma_{z}=0.5$, we obtain a $68 \%$ replacement ratio, close to that in the baseline model.

For this parameterisation, Figure 5 shows the impulse responses. As in the baseline, the monetary stimulus has a large effect on wages. However, unemployment falls much more than it does in the baseline model, because firms strongly decrease the separation rate at the same time that they increase hiring (green squares). The behaviour of inflation is similar to that in the baseline; productivity dynamics show only mild selection effects from endogenous separation, since our calibration implies that, in steady state, only $2.4 \%$ of jobs separate due to idiosyncratic productivity shocks. 
Notably, we find that all adjustment margins comove to make labor use procyclical: a monetary easing leads to a rise in vacancies, hours per worker, and wages, as well as a fall in the separation rate and in unemployment. Many papers with endogenous separation have instead found counterfactual comovements across these margins; for example, Krause and Lubik (2007) find a positive Beveridge correlation under Nash bargaining and endogenous separation. Indeed, in an earlier version of the present paper (Christoffel et al., 2009a), which assumed vacancies could only be filled after a one-period lag, unemployment was positively correlated with vacancies and/or hours, depending on parameters. The assumption that labour can be adjusted immediately on all margins turns out to be a simple way of ensuring that the comovement of all these margins is consistent with the data.

\section{$5 \quad$ Summary and sensitivity analysis}

Our results so far are summarised in Table 4. The table shows that some of the model variants, namely the RTM model with sticky wages and the model with firm-level real rigidity, succeed in curbing the inflation response, and even imply too much real rigidity. Similarly for wages. However, these same model variants have a much weakerl performance as regards employment dynamics.

In that respect, the efficient bargaining model with sticky wages does best, but does not succeed in producing a mild response of inflation. In the baseline calibration therefore none of the models gives a convincing account of inflation, wage and employment dynamics at the same time. While the mechanisms that we highlighted are independent of the calibration, the literature has repeatedly emphasized that different calibrations of the search and matching model can alter considerably the conclusions with respect to the model's fit. (See, eg, Shimer (2005), Hagedorn and Manovskii (2008) and Trigari (2006).) In that light, the next section looks at the effects of changing the curvature of the disutility of work, $\phi .^{19}$

\footnotetext{
${ }^{19} \mathrm{We}$ also assessed the sensitivity of our results with respect to the outside option of the worker by increasing the replacement ratio, parameter $b$. This experiment gave very similar results as a decrease
} 


\begin{tabular}{l|r|r|r|l|r}
\hline & Output & Inflation & $\begin{array}{l}\text { Unem- } \\
\text { ployment } \\
\text { rate }\end{array}$ & $\begin{array}{l}\text { Real } \\
\text { wage per } \\
\text { hour }\end{array}$ & $\begin{array}{l}\text { Hours } \\
\text { per } \\
\text { employee }\end{array}$ \\
\hline \hline Euro area data & 0.7 & 0.4 & -0.47 & 0.2 & 0.1 \\
\hline Baseline (eff. barg.) & 0.5 & 2.0 & -0.17 & 2.4 & 0.3 \\
RTM bargaining & 0.5 & 2.3 & -0.04 & 4.5 & 0.4 \\
Sticky wages (EB) & 0.7 & 1.3 & -0.36 & 0.1 & 0.3 \\
Sticky wages (RTM) & 1.1 & 0.0 & -0.12 & 0.0 & 1.0 \\
Firm-level real rigidity & 1.0 & 0.2 & -0.04 & 0.04 & 1.0 \\
Alternative hiring costs & 0.6 & 2.0 & -0.25 & 2.6 & 0.3 \\
On-the-job search & 0.6 & 1.7 & -0.31 & 2.0 & 0.2 \\
Endog. separation & 0.6 & 1.7 & -0.32 & 1.8 & 0.4 \\
\hline \hline
\end{tabular}

Table 4: Maximum Responses to A 100 Bps monetary EAsing in the Models AND IN THE DATA. Baseline calibration. Top row: euro area data. Then: baseline model with efficient bargaining (EB) and right-to-manage bargaining (RTM); models with EB and RTM and sticky wages for new and existing matches; real rigidities arising at the firm-level due to firm-specific labour; alternative hiring costs; on-thejob search and endogenous separation. Relative to the baseline, each of the models changes one feature at a time.

\subsection{Sensitivity analysis}

A crucial parameter for the response of wages, employment and inflation in the above variants is the curvature of the disutility of work, $\phi$. On the one hand, the lower is $\phi$, the less responsive are aggregate hourly wages to the business cycle and the less responsive is inflation. This increases the response of output and, thus, of unemployment too, and may in some of the model variants reduce the response of inflation. On the other hand, a lower disutility of work also means that it is less costly for firms, at the margin, to make recourse to the intensive margin than with a higher disutility of work, which could reduce incentives for firms to hire new workers. Finally, our calibration strategy implies a third avenue through which the disutility of work influences the response of the economy: the steady-state value of a job for the firms. In the baseline efficient bargaining model, for example, steady-state wages depend linearly on $\frac{1}{1+\phi}$ (recall, in steady state $h=1$ ). So in the calibration, the lower the disutility of work, the higher are steady-state wages and the lower are the steady-state profits associated with a job $\left(\mathcal{J}_{t}\right)$. By the logic detailed in Hagedorn and Manovskii (2008), this in turn means in $\phi$. Given that, we do not report these results in the paper but they are available on request. 
that the hiring margin, for some of the models, will be more responsive to shocks. For comparison, Table 6 in the Appendix shows the steady-state value of $\mathcal{J}$ for each of the model variants and calibrations. In sum, a lower disutility of work can be expected to reduce the responses of inflation and wages to monetary policy, which brings most model variants closer to the data. Ex ante, the effect with respect to the unemployment response is ambiguous, however.

\begin{tabular}{l|r|r|l|l|r}
\hline & Output & Inflation & $\begin{array}{l}\text { Unem- } \\
\text { ployment } \\
\text { rate }\end{array}$ & $\begin{array}{l}\text { Real } \\
\text { wage per } \\
\text { hour }\end{array}$ & $\begin{array}{l}\text { Hours } \\
\text { per } \\
\text { employee }\end{array}$ \\
\hline \hline Euro area data & 0.7 & 0.4 & -0.47 & 0.2 & 0.1 \\
\hline \hline Baseline (eff. barg.) & 0.7 & 1.0 & -0.57 & 1.0 & 0.1 \\
RTM bargaining & 0.6 & 1.4 & -0.05 & 2.0 & 0.6 \\
Sticky wages (EB) & 0.9 & 0.5 & -0.99 & 0.1 & -0.4 \\
Sticky wages (RTM) & 1.1 & 0.0 & -0.11 & 0.0 & 1.0 \\
Firm-level real rigidity & 1.0 & 0.3 & +0.10 & 0.0 & 1.0 \\
Alternative hiring costs & 0.8 & 0.9 & -0.68 & 0.9 & -0.2 \\
On-the-job search & 0.8 & 0.6 & -0.79 & 0.6 & -0.0 \\
Endog. separation & 0.8 & 0.7 & -0.60 & 0.1 & 0.2 \\
\hline \hline
\end{tabular}

Table 5: Maximum Responses to a 100 bPS Monetary EASING IN The Models AND IN THE DATA, $\phi=2$. Modifies the baseline calibration to allow for lower curvature of the disutility of work, $\phi$. Top row: euro area data. Then: baseline model with efficient bargaining (EB) and right-to-manage bargaining (RTM); models with EB and RTM and sticky wages for new and existing matches; real rigidities arising at the firm-level due to firm-specific labour; alternative hiring costs; on-the-job search and endogenous separation. Relative to the baseline, each of the models changes one feature at a time.

As expected given the key role of $\phi$ in the determination of marginal cost (see, e.g., equation 19), decreasing $\phi$ decreases significantly the response of inflation and wages in the models with efficient bargaining. This amplifies the reaction of employment, as does the indirect steady-state effect discussed above, that works through the value of jobs to firms. As a result, the responses of inflation and wages in the efficient bargaining model with stickiness in the wages of new hires become more consistent with the data, albeit now at the cost of an excessive response of unemployment. For right-to-manage, as discussed in Section 4.1, $\phi$ influences the implicit bargaining weight for the worker. Therefore, wages react by less, as does inflation, via the wage channel inherent in that model. The effect on the hiring margin is small. Indeed, Christoffel and Kuester (2008) 
show that with RTM there is a tight positive relationship between the fluctuations of wages per employee and the profitability of jobs up to first order; thus a reduction in the wage response does not necessarily lead to more fluctuations in hiring in that bargaining scheme.

While bargaining is also efficient in the model with firm-level real rigidities, the mechanisms are sufficiently different to merit a discussion. First, a lower $\phi$ implies that the real rigidities induced by the firm-specificity of labour are weaker than in the baseline, so inflation is more responsive to the shock. It is also interesting to note that the unemployment response switches sign, which is at odds with the data. In the firmspecific labour model, profits associated with jobs have two components: that resulting from the job match itself and the markup. A lower disutility of work squeezes the importance of the profits associated with the job match itself, and increases the relative importance of the markup component, which is countercyclical. As a result, the response of unemployment flips sign.

To summarize, our alternative calibration helps to get some responses of certain model variants more in line with the data. But, also under the alternative calibration assessed here, none of the model variants matches simultaneously the five stylised facts for the monetary transmission in the euro area laid out in Section 3. Indeed, an advantage of the calibration strategy for the baseline case was that it disciplined alternative calibrations.

\section{Conclusions}

In this paper, we have assessed the ability of many variants of a New Keynesian model with labor market frictions to explain wage, employment and inflation dynamics. We have used as our empirical benchmark the responses of these variables to a monetary policy shock in the euro area. We used a standard New Keynesian model, augmented with search and matching frictions and efficient bargaining over wages and hours to show that such models typically generate a response of inflation to nominal shocks that is much too large relative to the data. We then considered many, if not most, of the 
alternative specifications that currently exist in the literature.

We first considered the addition of wage rigidity. Under efficient bargaining, wage stickiness in existing jobs has no effect, since average wages in existing jobs are nonallocative. But wage stickiness in newly created jobs does have an effect that brings the model closer to the data in all dimensions. Combined with a 'right-to-manage' assumption for the determination of hours (which implies a direct channel from wages to inflation), staggered wages at the level of the match help to smooth the reaction of the aggregate wage, resulting in a smaller response to shocks of inflation, in fact too small a response But, the model failed to replicate the dynamics of employment and hours worked. We then combined this nominal wage rigidity with the real rigidity of firm-specific labour. Here, too, the additional real rigidity curbed the inflation response, as desired, but also dampened the unemployment response, further moving the labour market responses away from the data. Given the central role of the intensive margin for employment dynamics, and thus in turn for marginal costs, we then looked at a variant of the hiring cost function that has been proposed to imply stronger and more persistent employment fluctuations. We found that this somewhat helped for the unemployment response, but not enough to notably improve upon the wage and inflation responses in the baseline. Finally, we considered two other margins along which adjustment can occur in the labour market: on-the-job search and endogenous job destruction. We found that both features helped to increase the response of unemployment to shocks, but not enough to imply a sufficiently weak response of inflation.

In summary, we found that some of the model variants greatly improved the hours and employment response relative to the baseline, bringing the implications of the model closer to the data. However, the model variants that showed a realistic response of unemployment and hours worked tended to do less well in replicating the attenuated response of inflation, signaling too little real rigidity. By the same token, those model variants that fared better with regard to the inflation response, had a harder time producing reasonably strong unemployment fluctuations. Not surprisingly, a larger set of model variants was, however, able to fit the wage dimension. 
More generally, our results suggest that solving employment and wage dynamics alone does not hold the key to reasonable inflation dynamics. Other approaches to modeling the labour market seem to be needed to reconcile inflation, wage and employment dynamics, or there may be a need for additional sources of real rigidity from outside of the labour market. 


\section{References}

[1] Álvarez, L., E. DHYNE, M. HOEBERICHTS, C. KWAPIL, H. LE BIHAN, P. LÜNNEMANN, F. MARTINS, R. SABBATINI, H. STAHL, P. VERMEULEN and J. VILMUNEN (2006). "Sticky prices in the euro area: a summary of new micro evidence", Journal of the European Economic Association, Vol. 4, pp. 575584 .

[2] ANGELONI, I., A. KASHYAP, B. MOJON and D. TERLIZZESE (2003). "The output composition puzzle: a difference in the monetary transmission mechanism in the euro area and United States", Journal of Money, Credit, and Banking, Vol. 35 , pp. $1265-1306$.

[3] BLANCHARD, O., and J. GALÍ (2006). A New Keynesian model with unemployment, National Bank of Belgium Working Paper No. 92.

[4] - (2007). "Real wage rigidities and the New Keynesian model", Journal of Money, Credit and Banking, Vol. 39, pp. 35-65.

[5] — (2009). "Labor Markets and Monetary Policy: A New-Keynesian Model with Unemployment", forthcoming: American Economic Journal: Macroeconomics.

[6] BODART, V., G. DE WALQUE, O. PIERRARD, H. SNEESSENS and R. WOUTERS (2006). Nominal wage rigidities in a New Keynesian model with frictional unemployment, IZA Discussion Paper No. 2528.

[7] BODART, V., O. PIERRARD and H. SNEESSENS (2005). Calvo wages in a search unemployment model, DNB Working Paper No. 68.

[8] BURDA, M., and C. WYPLOSZ (1994). "Gross worker and job flows in Europe", European Economic Review, Vol. 38, pp. 1287-1315.

[9] CHRistiano, L., M. EICHENBAUM and C. EVANS (2005). "Nominal rigidities and the dynamic effects of a shock to monetary policy", Journal of Political Economy, Vol. 113, pp. 1-45.

[10] CHRISTOFFEL, K., J. COSTAIN, G. DE WALQUE, K. KUESTER, T. LINZERT, S. MILLARD and O. PIERRARD (2009). Inflation dynamics with labour market matching: assessing alternative specifications, ECB Working Paper No. 1053.

[11] CHRISTOFFEL, K., and K. KUESTER (2008). "Resuscitating the wage channel in models with unemployment fluctuations", Journal of Monetary Economics, Vol. 55 (5), pp. 865-887. 
[12] CHRISTOFFEL, K., K. KUESTER and T. LINZERT (2009). "The role of labor markets for euro area monetary policy", European Economic Review, forthcoming.

[13] CHRISTOFFEL, K., and T. LINZERT (2005). The role of real wage rigidity and labor market frictions for unemployment and inflation dynamics, ECB Working Paper No. 556.

[14] DAVIS, S., J. HALTIWANGER and S. SCHUH (1996). Job Creation and Destruction, MIT Press, Cambridge, Mass.

[15] DEN HAAN, W., G. RAMEY and J. WATSON (2000). "Job destruction and propagation of shocks", American Economic Review, Vol. 90, pp. 482-498.

[16] DU CAJU, P., E. GAUTIER, D. MOMFERATOU and M. WARDWARMEDINGER (2008). Institutional features of wage bargaining in 22 EU countries, the US and Japan, European Central Bank Working Paper No. 974.

[17] ERCEG, C., D. HENDERSON and A. LEVIN (2000). "Optimal monetary policy with staggered wage and price contracts", Journal of Monetary Economics, Vol. 46(2), pp. 281-313.

[18] EVERS, M., R. A. D. MOOIJ and D. J. V. VUUREN (2005). What explains the variation in estimates of labour supply elasticities?, CESifo Working Paper No. 1633.

[19] FUJITA, S., and G. RAMEY (2007). "Job matching and propagation", Journal of Economic Dynamics and Control, Vol. 31 (11), pp. 3671-3698.

[20] GERTLER, M., and A. TRIGARI (2006). Unemployment fluctuations with staggered Nash wage bargaining, NBER Working Paper No. 12498.

[21] HALL, R. E. (2005). "Employment fluctuations with equilibrium wage stickiness", American Economic Review, Vol. 95, pp. 50-65.

[22] KRAUSE, M., and T. LUBIK (2006). "The cyclical upgrading of labour and onthe-job search", Labour Economics, Vol. 13, pp. 459-477.

[23] — (2007). "The (ir)relevance of real wage rigidity in the New Keynesian model with search frictions", Journal of Monetary Economics, Vol. 54, pp. 706-727.

[24] KUESTER, K. (2007). Real price and wage rigidities in a model with matching frictions, European Central Bank Working Paper No. 720.

[25] MCCALLUM, A., and F. SMETS (2008). Real wages and monetary policy transmission in the euro area, European Central Bank, mimeo. 
[26] MORTENSEN, D., and E. NAGYPAL (2007). "More on unemployment and vacancy fluctuations", Review of Economic Dynamics, Vol. 10, pp. 327-347.

[27] MORTENSEN, D., and C. A. PISSARIDES (1994). "Job creation and job destruction in the theory of unemployment", Review of Economic Studies, Vol. 61, pp. 397-415.

[28] — (1999). "Job reallocation, employment fluctuations and unemployment", in J. Taylor and M. Woodford (eds.), Handbook of Macroeconomics, Vol. 1, Amsterdam, North-Holland, pp. 1171-1228.

[29] PEERSMAN, G., and F. SMETS (2003). "The monetary transmission mechanism in the euro area: More evidence from VAR analysis", in I. Angeloni, A. Kashyap and B. Mojon (eds.), Monetary Policy Transmission in the Euro Area, Cambridge University Press, Cambridge, United Kingdom.

[30] PEERSMAN, G., and R. STRAUB (2007). Putting the New Keynesian model to a test, European Central Bank, mimeo.

[31] PetrongOLO, B., and C. A. PISSARIDES (2001). "Looking into the black box: A survey of the matching function", Journal of Economic Literature, Vol. 39, pp. 390-431.

[32] PHILLIPS, A. W. (1958). "The relation between unemployment and the rate of change of money wage rates in the United Kingdom, 1861-1957", Economica, Vol. 25, pp. 283-299.

[33] SHIMER, R. (2005). "The cyclical behaviour of equilibrium unemployment and vacancies", American Economic Review, Vol. 95, pp. 25-49.

[34] SVEEN, T., and L. WEINKE (2007). Inflation dynamics and labour market dynamics revisited, Kiel Institute for the World Economy Working Paper No. 1368.

[35] THOMAS, C. (2008). Search frictions, real rigidities and inflation dynamics, Banco de España Working Paper No. 0806.

[36] TRIGARI, A. (2006). The role of search frictions and bargaining for inflation dynamics, IGIER Working Paper No. 304.

[37] — (2009). "Equilibrium unemployment, job flows, and inflation dynamics", Journal of Money, Credit and Banking, Vol. 41 (1), pp. 1-33.

[38] VAN ZANDWEGHE, W. (2009). On-the-job search, sticky prices and persistence, FRB Kansas City Working Paper 09-03. 
[39] WALSH, C. (2005). "Labour market search, sticky prices, and interest rate policies", Review of Economic Dynamics, Vol. 8, pp. 829-849.

[40] WOODFORD, M. (2003). Interest and Prices, Princeton University Press, Princeton.

[41] YASHIV, E. (2006). "Evaluating the performance of the search and matching model", European Economic Review, Vol. 50, pp. 909-936. 


\section{Implied parameters and steady states}

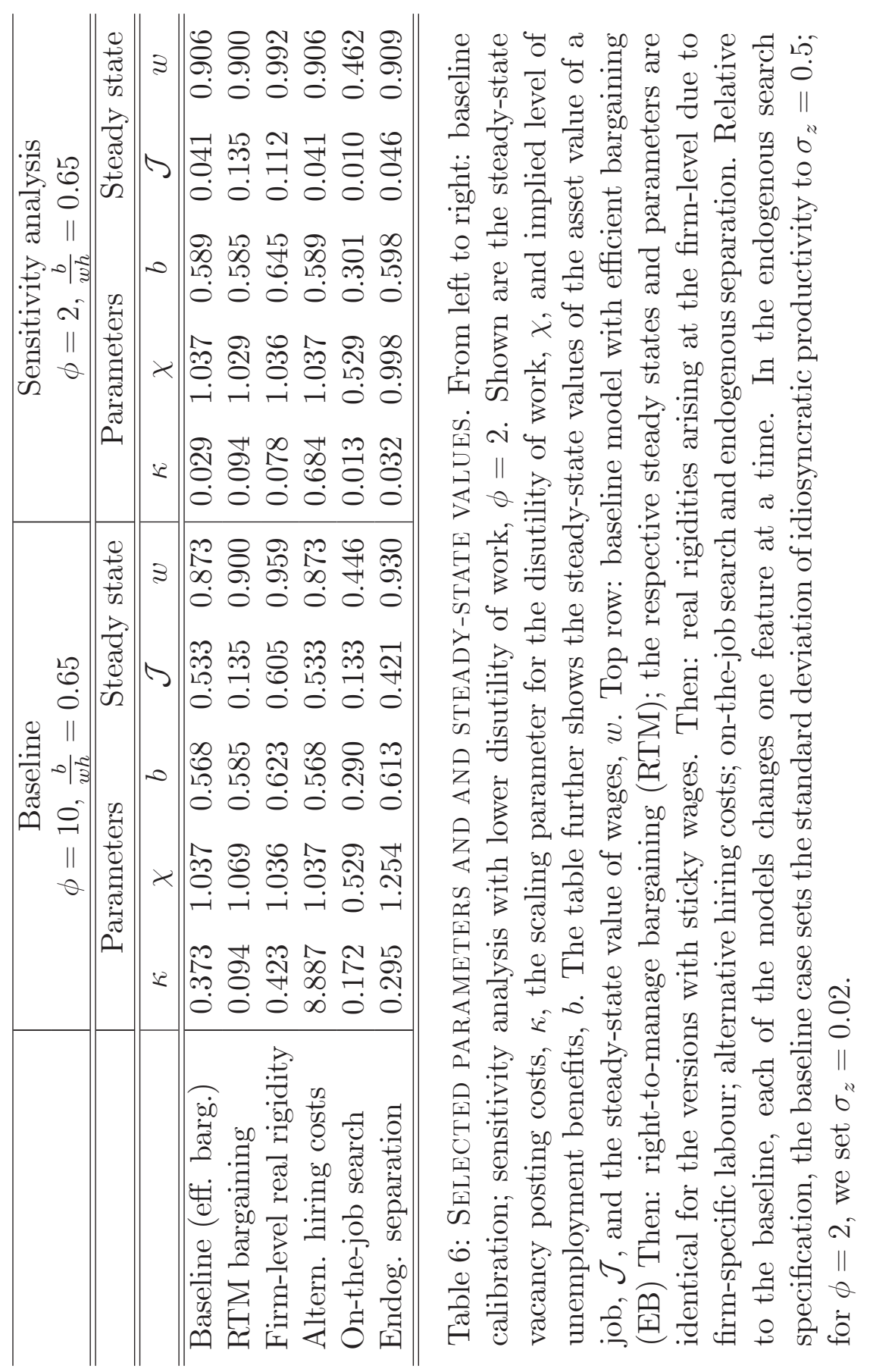


BANCO DE ESPAÑA PUBLICATIONS

\section{WORKING PAPERS ${ }^{1}$}

0801 ENRIQUE BENITO: Size, growth and bank dynamics.

0802 RICARDO GIMENO AND JOSÉ MANUEL MARQUÉS: Uncertainty and the price of risk in a nominal convergence process.

0803 ISABEL ARGIMÓN AND PABLO HERNÁNDEZ DE COS: Los determinantes de los saldos presupuestarios de las Comunidades Autónomas.

0804 OLYMPIA BOVER: Wealth inequality and household structure: US vs. Spain.

0805 JAVIER ANDRÉS, J. DAVID LÓPEZ-SALIDO AND EDWARD NELSON: Money and the natural rate of interest: structural estimates for the United States and the euro area.

0806 CARLOS THOMAS: Search frictions, real rigidities and inflation dynamics.

0807 MAXIMO CAMACHO AND GABRIEL PEREZ-QUIROS: Introducing the EURO-STING: Short Term INdicator of Euro Area Growth.

0808 RUBÉN SEGURA-CAYUELA AND JOSEP M. VILARRUBIA: The effect of foreign service on trade volumes and trade partners.

0809 AITOR ERCE: A structural model of sovereign debt issuance: assessing the role of financial factors.

0810 ALICIA GARCÍA-HERRERO AND JUAN M. RUIZ: Do trade and financial linkages foster business cycle synchronization in a small economy?

0811 RUBÉN SEGURA-CAYUELA AND JOSEP M. VILARRUBIA: Uncertainty and entry into export markets.

0812 CARMEN BROTO AND ESTHER RUIZ: Testing for conditional heteroscedasticity in the components of inflation.

0813 JUAN J. DOLADO, MARCEL JANSEN AND JUAN F. JIMENO: On the job search in a model with heterogeneous jobs and workers.

0814 SAMUEL BENTOLILA, JUAN J. DOLADO AND JUAN F. JIMENO: Does immigration affect the Phillips curve? Some evidence for Spain.

0815 ÓSCAR J. ARCE AND J. DAVID LÓPEZ-SALIDO: Housing bubbles.

0816 GABRIEL JIMÉNEZ, VICENTE SALAS-FUMÁS AND JESÚS SAURINA: Organizational distance and use of collateral for business loans.

0817 CARMEN BROTO, JAVIER DÍAZ-CASSOU AND AITOR ERCE-DOMÍNGUEZ: Measuring and explaining the volatility of capital flows towards emerging countries.

0818 CARLOS THOMAS AND FRANCESCO ZANETTI: Labor market reform and price stability: an application to the Euro Area.

0819 DAVID G. MAYES, MARÍA J. NIETO AND LARRY D. WALL: Multiple safety net regulators and agency problems in the EU: Is Prompt Corrective Action partly the solution?

0820 CARMEN MARTÍNEZ-CARRASCAL AND ANNALISA FERRANDO: The impact of financial position on investment: an analysis for non-financial corporations in the euro area.

0821 GABRIEL JIMÉNEZ, JOSÉ A. LÓPEZ AND JESÚS SAURINA: Empirical analysis of corporate credit lines.

0822 RAMÓN MARÍA-DOLORES: Exchange rate pass-through in new Member States and candidate countries of the EU.

0823 IGNACIO HERNANDO, MARÍA J. NIETO AND LARRY D. WALL: Determinants of domestic and cross-border bank acquisitions in the European Union.

0824 JAMES COSTAIN AND ANTÓN NÁKOV: Price adjustments in a general model of state-dependent pricing.

0825 ALFREDO MARTÍN-OLIVER, VICENTE SALAS-FUMÁS AND JESÚS SAURINA: Search cost and price dispersion in vertically related markets: the case of bank loans and deposits.

0826 CARMEN BROTO: Inflation targeting in Latin America: Empirical analysis using GARCH models.

0827 RAMÓN MARÍA-DOLORES AND JESÚS VAZQUEZ: Term structure and the estimated monetary policy rule in the eurozone.

0828 MICHIEL VAN LEUVENSTEIJN, CHRISTOFFER KOK SØRENSEN, JACOB A. BIKKER AND ADRIAN VAN RIXTEL: Impact of bank competition on the interest rate pass-through in the euro area.

0829 CRISTINA BARCELÓ: The impact of alternative imputation methods on the measurement of income and wealth: Evidence from the Spanish survey of household finances.

0830 JAVIER ANDRÉS AND ÓSCAR ARCE: Banking competition, housing prices and macroeconomic stability.

0831 JAMES COSTAIN AND ANTÓN NÁKOV: Dynamics of the price distribution in a general model of state-dependent pricing.

1. Previously published Working Papers are listed in the Banco de España publications catalogue. 
0832 JUAN A. ROJAS: Social Security reform with imperfect substitution between less and more experienced workers.

0833 GABRIEL JIMÉNEZ, STEVEN ONGENA, JOSÉ LUIS PEYDRÓ AND JESÚS SAURINA: Hazardous times for monetary policy: What do twenty-three million bank loans say about the effects of monetary policy on credit risk-taking?

0834 ENRIQUE ALBEROLA AND JOSÉ MARÍA SERENA: Sovereign external assets and the resilience of global imbalances.

0835 AITOR LACUESTA, SERGIO PUENTE AND PILAR CUADRADO: Omitted variables in the measure of a labour quality index: the case of Spain.

0836 CHIARA COLUZZI, ANNALISA FERRANDO AND CARMEN MARTíNEZ-CARRASCAL: Financing obstacles and growth: An analysis for euro area non-financial corporations.

0837 ÓSCAR ARCE, JOSÉ MANUEL CAMPA AND ÁNGEL GAVILÁN: asymmetric collateral requirements and output composition.

0838 ÁNGEL GAVILÁN AND JUAN A. ROJAS: Solving Portfolio Problems with the Smolyak-Parameterized Expectations Algorithm.

0901 PRAVEEN KUJAL AND JUAN RUIZ: International trade policy towards monopoly and oligopoly.

0902 CATIA BATISTA, AITOR LACUESTA AND PEDRO VICENTE: Micro evidence of the brain gain hypothesis: The case of Cape Verde.

0903 MARGARITA RUBIO: Fixed and variable-rate mortgages, business cycles and monetary policy.

0904 MARIO IZQUIERDO, AITOR LACUESTA AND RAQUEL VEGAS: Assimilation of immigrants in Spain: A longitudinal analysis.

0905 ÁNGEL ESTRADA: The mark-ups in the Spanish economy: international comparison and recent evolution.

0906 RICARDO GIMENO AND JOSÉ MANUEL MARQUÉS: Extraction of financial market expectations about inflation and interest rates from a liquid market.

0907 LAURA HOSPIDO: Job changes and individual-job specific wage dynamics.

0908 M. ${ }^{a}$ DE LOS LLANOS MATEA AND JUAN S. MORA: La evolución de la regulación del comercio minorista en España y sus implicaciones macroeconómicas.

0909 JAVIER MENCÍA AND ENRIQUE SENTANA: Multivariate location-scale mixtures of normals and mean-varianceskewness portfolio allocation

0910 ALICIA GARCÍA-HERRERO, SERGIO GAVILÁ AND DANIEL SANTABÁRBARA: What explains the low profitability of Chinese banks?

0911 JAVIER MENCÍA: Assessing the risk-return trade-off in loans portfolios.

0912 MAXIMO CAMACHO AND GABRIEL PEREZ-QUIROS: Ñ-STING: España Short Term INdicator of Growth.

0913 RAQUEL VEGAS, ISABEL ARGIMÓN, MARTA BOTELLA AND CLARA I. GONZÁLEZ: Retirement behaviour and retirement incentives in Spain.

0914 FEDERICO CINGANO, MARCO LEONARDI, JULIÁN MESSINA AND GIOVANNI PICA: The effect of employment protection legislation and financial market imperfections on investment: Evidence from a firm-level panel of EU countries.

0915 JOSÉ MANUEL CAMPA AND IGNACIO HERNANDO: Cash, access to credit, and value creation in M\&As.

0916 MARGARITA RUBIO: Housing market heterogeneity in a monetary union.

0917 MAXIMO CAMACHO, GABRIEL PEREZ-QUIROS AND HUGO RODRÍGUEZ MENDIZÁBAL: High-growth Recoveries, Inventories and the Great Moderation.

0918 KAI CHRISTOFFEL, JAMES COSTAIN, GREGORY DE WALQUE, KEITH KUESTER, TOBIAS LINZERT, STEPHEN MILLARD AND OLIVIER PIERRARD: Wage, inflation and employment dynamics with labour market matching.

\section{BANCODEESPAÑA} Eurosistema
Unidad de Publicaciones Alcalá, 522; 28027 Madrid

Telephone +34 91338 6363. Fax +34913386488 E-mail: publicaciones@bde.es www.bde.es 